\title{
A Glimpse of the de Rham Era
}

\section{by Srishti Chatterji and Manuel Ojanguren}

\author{
EPFL, SB IMA and IGAT, EPFL
}

\section{Introduction}

The life of Georges de Rham (1903-1990) covered most of the momentous twentieth century, whose extraordinary events are still affecting our lives to-day. The developments in mathematics which took place during the period of de Rham's mathematical career, roughly the halfcentury 1925-1975, in which de Rham himself played a significant role, are still very much present in modern mathematics. The de Rham era to which the title of the article refers, is to be understood as concerning the years (approximately) 1925-1975; the year 1925 marks the year of de Rham's graduation from the University of Lausanne and his launching into mathematical research; by 1975 de Rham had officially retired from his professorial positions at the Universities of Lausanne and Geneva. Our modest aim is to allow interested readers to have some glimpses of certain events during this era which we have been privileged to acquire through a perusal of de Rham's extensive correspondence (and other papers) to which we had access. Naturally, we have supplemented this by a study of his collected papers [1], of several memoirs and historical studies by others (referred to subsequently) and finally an interesting brochure [2] produced by de Rham's friends, students and collaborators in 1995. We do not claim any historical exhaustiveness, the aim being one of offering an impressionistic glimpse, based however on written documentation. We do not attempt to write a biography of de Rham, although some of the basic biographical elements will be enumerated so that those who were not privileged to have known him will have some idea of this major figure in mathematics of twentieth century Swiss Romande. We shall attempt to portray de Rham's interactions with some of the most prominent mathematicians of his time and the role he played in the development of mathematics locally (in Swiss Romande) nationally (in Switzerland) and internationally. In this year of the hundredth anniversary of the Swiss Mathematical Society (founded in 1910) it seems worthwhile to recapitulate some of the events in Swiss mathematical life as seen through the personal papers of an eminent member of the Society.

Since this essay is written with an international readership in view, some facts which are well-known to Swiss mathematicians will be reviewed briefly as introductory material. Then we will present a succinct sketch of de Rham's biography, followed by a concise presentation of his mathematical work in very general terms, which should be accessible to non-specialists. Then we shall present a few isolated episodes which are either not well-known or else poorly understood. We shall indicate de Rham's farflung connexions with the most eminent mathematicians of his time and his activities in local, national, and international circles. Several documents (mostly unpublished letters) have been appended (referred to as document $\mathbf{n}$, $\mathbf{n}=\mathbf{1}, \mathbf{2}, \ldots$ ) just before the bibliography.

\section{Review of Some Historical and Other Facts}

The present constitution of Switzerland is a modification of that of 1848 which, in its actual form divides the country into 23 cantons, of which three are further subdivided into two semi-cantons (these being Appenzell, Basel, Unterwalden). Each canton or semi-canton is sovereign in all internal as well as financial matters (in particular education) and the federal government, with its seat in Bern, has supremacy in a few well-defined areas (summed up by the competencies of the seven federal ministries which together form the federal government). This is not the place to discuss the nature and the constitution of the federal and the various cantonal parliaments and their respective judiciary systems but one point is important to our narrative: only ten of the cantons have a university, these being Basel, Bern, Zurich, Fribourg, Geneva, Vaud, Neuchâtel, St. Gallen, Ticino and Lucerne. Of these, only the first seven will concern us, St. Gallen's mathematical activities having been always rather limited and the last two being recent creations which do not enter our narrative at all ${ }^{1}$. Only the University of Basel can be called really ancient, being created in 1460 as the result of the workings of a controversial Council of the Church (called Council of Basel (1431-1449)). Of course, it was the University of Basel which had put Switzerland definitely in the centre of the history of mathematics, having brought forth such illustrious mathematicians as Jakob Bernoulli (1654-1705), Johann Bernoulli (1667-1748), Daniel Bernoulli (1700-1782), many other remarkable Bernoullis and finally, and most famously, Leonhard Euler (1707-1783), although the last named spent most of his life (from 1727 onwards) exclusively in Russia (St. Petersburg) and in Prussia (Berlin).

All the six other Swiss universities date from after the 1830's: Zurich (1833), Bern (1834), Geneva (1872), Fribourg (1889), Lausanne (in Canton Vaud, 1890), Neuchâtel (1909). Of course, all of these other universities had sprung from much older institutions (mostly 16th century or older) but none could be called a university previously. A major novelty introduced by the 1848 Federal Constitution was the

${ }^{1}$ St. Gallen 1898, Ticino 1996, Lucerne 2005. 
possibility on the part of the federal government of creating a Federal Technical University. This latter finally came into being in 1855 in the form of the Eidgenössische Technische Hochschule (ETH). Much later, in 1969, a Frenchlanguage form of the ETH was created in Lausanne as École Polytechnique Fédérale de Lausanne (EPFL) which was in fact a federalisation of an engineering school associated with the University of Lausanne in one form or another since 1853 (i.e. predating the official declaration of the Academy in Lausanne as a University). In its last metamorphosis as a part of the University of Lausanne, it was called École Polytechnique de l'Université de Lausanne, with the acronym EPUL which stuck with it for many years in the local population. The creation of EPFL in 1969 correspondingly brought in EPFZ as the French acronym for ETH and ETHZ as the German acronym for ETH in current usage (cf. [6] for more on this),

Right from the beginning of Switzerland's creation (in 1291) the problems of language and religion were important factors of discord and dispute which have now happily come to a stable solution. Without going into any details of this complicated history, let us state the present situation: the cantons of Geneva, Vaud, Neuchâtel and Jura (created in 1978) are French speaking, Ticino is Italian speaking, Bern, Fribourg and Valais are officially bilingual (French and German), Graubünden is trilingual (German, Italian and Romansh) and all the other cantons have German as official language. It is traditional to refer to the French speaking Swiss as "Swiss Romand" (similarly "Swiss German", "Swiss Italian”).

Religion is a more complicated issue; some cantons are considered catholic, others protestant, others secular; fortunately this discussion need not concern us here at all since these problems are a matter of past history.

Some idea of the relative demographic importance of the different linguistic groupings is useful to have, although this obviously varies in time. A general statement like 70\% German speaking, 20\% French, and 10\% Italian and Romansh is not accurate, but probably gives a fair average description of the situation. The population of the country is over 7.7 million today; in de Rham's youth it was closer to 4 million. Because of the multilingual character of the country, it is not uncommon to meet University people well-versed in several languages; in theory, everyone is supposed to be bilingual - the language of the canton and another official language. The reality, however, is far from this ideal theory. At least in de Rham's days, a Swiss German could read and understand French and/or Italian and a Romand (like de Rham) could read and understand German and/or Italian. By his own admission, de Rham was not a good linguist; his English remained essentially functional (he could read and, with help, write in English). But he read German with ease and on several important occasions read Spanish (as we shall see). Of the 61 items listed in de Rham's collected works [1] all but 4 are in French, 1 in German ([10] in [1]), 3 in English ([39], [49], [54] in [1]); his famous book Variétés différentiables. Formes, courants, formes harmoniques (1st ed. 1953, 2nd ed. 1960, 3rd ed.
1973) was later translated into English (Springer 1984), in Russian (1956) and perhaps in other languages. An important oversight in the bibliography of [1] is de Rham's lecture notes Lectures on an introduction to algebraic topology (notes by V.J. Lal, Tata Institute, Bombay, 1969).

To exemplify how much the creation of the ETH in 1855 accelerated mathematical activities in Switzerland, let us briefly mention the following. In 1897 the Zurich mathematicians organized the first International Congress of Mathematicians (ICM) in Zurich; we shall return to ICM's later. In 1907 the Société Helvétique des Sciences Naturelles (now called Swiss Academy of Sciences in English) created an Euler Commission for the publication of the complete works of Euler (of which the first volume appeared in 1911 and the last two of about 74 volumes is planned for completion in 2010) with the cooperation of many internationally renowned mathematicians under the organization of Swiss mathematicians. This showed up the need for a national mathematical society, finally established in 1910, named la Société Mathématique Suisse in French; the three founding members were Rudolf Fueter (University of Basel, 1880-1950), Henri Fehr (University of Geneva, 1870-1954) and Marcel Grossmann (ETH, 1878-1936); cf. the article by Michel Plancherel [8] on the occasion of the 50th anniversary of the SMS.

Besides these organizational accomplishments, we must name a few of the illustrious mathematicians who occupied professorial positions at the ETH during the last years of the 19th century: Joseph Ludwig Raabe (1801-1859), Richard Dedekind (1831-1916), Elwin Bruno Christoffel (1829-1900), Friedrich Emil Prym (1841-1915), Hermann Amandus Schwarz (1843-1921), Heinrich Weber (1843-1913), Georg Ferdinand Frobenius (1849-1917), Friedrich Hermann Schottky (1851-1935), Ferdinand Rudio (1856-1927), Adolf Hurwitz (1859-1919), Hermann Minkowski (1864-1909) to give the names of the most well-known amongst them. A more complete list and a discussion of their lives and works can be found in the work of Frei and Stammbach [4]. Another impressive list of names of those working at the University of Zurich during the same period can be found also in [4]. It seems clear that each of the two institutions in Zurich provided an incentive for the other to push forward further. Admittedly, the names we have cited are mostly of German origin (Raabe was of Austrian background) and most of them stayed in Zurich for a limited number of years; except for Frobenius who stayed for 17 years, Schottky for 10 years, and Hurwitz who died in Zurich in retirement (after having been there from 1892 onwards), all the others stayed in Zurich between 5 and 7 years. But, after all, they were all young men and it was natural in German speaking areas to transfer oneself to a more prestigious place (Göttingen, Berlin, etc.) or to one more conducive to one's family life. The important thing to notice is that the Federal Government (which supervised all the appointments at the ETH via an organization called the Schulrat) did not hesitate to go after the most promising mathematicians, irrespective of their nationality; this policy was also applied 
in other branches like Physics and Chemistry with comparable success. It should be understood here that the other cantonal universities are run by the cantonal governments; although they do receive financial support from federal sources, the politics of running those universities are entirely in the hands of the corresponding cantonal administrations; however, in the Swiss tradition of compromise and cooperation, there is naturally a great deal of coordination through well-established channels which we need not describe here in detail.

One last word on the evolving linguistic situation at the level of the Universities. In de Rham's time, it was a well-established practice that the Swiss Romands would generally write in French to their German speaking colleagues and, conversely, the latter would generally write in German to their Swiss Romand colleagues. A similar usage prevailed as regards lectures, whether at Colloquia or at the Swiss Mathematical Society meetings. This continued well into the 1990's; lately, an international brand of English has taken over the role of a lingua franca in translingual communications (as indeed can be seen more and more frequently at many international meetings). This would have made de Rham quite ill at ease.

\section{Some Biographical Elements}

Georges de Rham was born in 1903 in the small commune of Roche (present population about 900) situated in the district of Aigle of Canton Vaud; the town of Aigle (chef-lieu du district) is about $6.5 \mathrm{~km}$. from Roche and has a population of about 8000 now; the general area forms the eastern extremity of Canton Vaud and is surrounded by impressive mountains of the pre-Alps and the Alps. It is therefore not surprising that young Georges became an enthusiastic mountaineer and eventually a very professional and competent mountain climber, a venture which he pursued round the globe until the ripe old age of 78. Georges' father Léon de Rham was a well-to-do engineer working for a railway construction enterprise; Georges was the fifth offspring of a family of six children (5 sons, 1 daughter, the eldest) all of whom led successful lives. Georges de Rham has himself given an account of his happy childhood in [2] from which we gather that his first 16 years were spent in Roche, attending college at Aigle (collège in Canton Vaud normally started at the age of 11 , preceded by 4-5 years of primary school which must have been in Roche). The family moved to Lausanne in 1919 where Georges entered the Gymnase classique (section Latin and Greek) to complete his higher secondary education in 1921. It is interesting to observe that the family moved into a set of apartments of the well-known Château de Beaulieu, in central Lausanne, which remained Georges de Rham's permanent address until the end of his life; thus 7, avenue des Bergières, Lausanne became a familiar address to all his many mathematical friends all over the world, many of whom stayed at this address when they came to Lausanne (as evidenced by several letters). Since Georges de Rham remained a bachelor all his life, for a while his mother seems to have acted as the hostess (his father having died in 1945). A study of the de Rham's family tree shows how extensive it is, and the surname de Rham flourishes in Canton Vaud and elsewhere. (A wealth of information on de Rham's family can be found in La famille de Rham: notes généalogiques, historiques et biographiques by Pierre de Rham, Saint-Sulpice, 1965, which is available at the Archives of Canton Vaud.)

We now come to de Rham's studies at the University of Lausanne between 1921-1925; again we have a fair description of this, both in [2] as well as in his autobiographical article (item [60] in [1]). His choice of mathematics as a specialization seems to have come to him rather late; in any case, he obtained his degree (licence en mathématiques) in 1925. As an illustration of the type of courses which de Rham might have followed, we have reproduced in document $\mathbf{1}$ the programme for the winter semester 1923/1924. An examination of the programmes of previous years does not show any significant differences. It will be noticed that the content of these programmes is very classical: differential and integral calculus, differential equations, function theory, analytic and descriptive geometry, probability etc. Note the fairly strong dose of descriptive geometry (9 hours a week), a subject much emphasized in continental Europe and almost unknown in English speaking countries. Until the development of computer technology in the 1980's and 1990's, descriptive geometry was compulsory material both at the first year university level (in almost all scientific studies) and at the higher secondary level (gymnase or lycée). One notices the absence of algebra and topology, the latter being still a nascent subject. However, one finds in programmes in Zurich (already in 1897/1898) such subjects as calculus of variations, number theory, geometry of numbers, projective geometry, theory of invariants (cf. [4]) and, by 1921, topics like group theory, elliptic modular functions and complex multiplication (ibid.).

To have some understanding of de Rham's mathematical development, one must know to some extent the mathematical personalities who were present during de Rham's studies at the University of Lausanne. As he himself has underlined, two mathematicians had considerable influence on him; the first was Gustave Dumas (1872-1955) who had been appointed as professeur extraordinaire of mathematics in 1913, professeur ordinaire in 1916 (eventually to retire in 1942) to teach differential and integral calculus and higher analysis. For more details concerning the history of the evolution of mathematics at the University of Lausanne (until 1990) one must consult the work [5] of Pierre-Denis Methée (born 1924), a student of de Rham and himself a professor of mathematics at the University of Lausanne for many years (chargé de cours 1953-1954, professeur extraordinaire 1955-1961, professeur ordinaire 1961-1991, retired 1991; cf. [5], p. 582). De Rham admired Dumas a great deal and ascribes to him the fact that he was led to reading the works of Poincaré, firstly the studies of Poincaré concerning curves defined by differential equations (which led him to try vainly for the solution of a famous unsolved problem (the second part of 
Hilbert's 16th problem)). For details see pp. 652-656 of de Rham's own exposition of this in [1]. The second important influence on de Rham was that of Dmitry Mirimanoff (1861-1945), a mathematician of Russian origin who had been in France since the age of 19 and eventually settled down in Geneva where he retired as a full professor in 1936. Mirimanoff's talent in mathematics was many-sided: from number theory to function theory as well as rather refined problems of set theory and probability theory, Mirimanoff's published work ranged over 60 items. Following Mirimanoff's advice, de Rham read up a great deal of classical function theory as well as the new books published by Borel, Baire and Lebesgue along with the standard work on algebra by Serret. But, as de Rham has admitted himself, he did not find function theory or real variable theory to his taste for doing research and went on to the less frequented path of the newly founded field of topology (analysis situs) as sketched out in Poincaré's prolific but somewhat mysterious papers on the subject, published over the years 1892-1905. (A modern analysis of all these has been bravely undertaken by Dieudonné in [3], Chapter 1). Gustave Dumas was a very well-rounded mathematician who in his youth had completed his formation in Paris, Berlin and Zurich; his published work covered a wide field ranging over algebra, analysis, and geometry. His work would be classified today as classical algebraic geometry (over the complex field) but fairly early he had taken a strong interest in Poincaré's papers in topology. Thus he induced his student Jules Chuard (1891-1967) to write a doctoral thesis in 1921 with the title Questions d'Analysis Situs, which was an attempt to clarify Poincaré's work in the special case of 2-dimensional complexes, with applications to surfaces. The following citation from his thesis may be interesting: "Mais nous n'étonnerons personne en constatant que la lecture" (of Poincaré's articles) "en est très aride. G. Darboux lui-même qualifie de difficiles les questions qui y sont traitées". Chuard's thesis was published in the Rendiconti of Palermo in 1922 and it was referred to in the well-known text of Seifert and Threlfall Lehrbuch der Topologie (1934). Dumas and Chuard also published a note in the Comptes Rendus of Paris in 1920 with the title Sur les homologies de Poincaré. Chuard went on to become a professor at the University of Lausanne but changed his field of research to combinatorics and probability theory. We have no indication of any mathematical connexion between de Rham and Chuard.

Before we go on with de Rham's career, we must mention the presence in Lausanne (from 1928 on) of a promising mathematician, Gustave Juvet (1896-1936) who unfortunately died unexpectedly, presumably of a heart failure while on a walking expedition in the Val d'Anniviers, in Valais (cf. Gustave Dumas' allocution published in [7] by the University of Lausanne). Juvet was a person of very wide interests; in mathematics, he can be characterized as a mathematical physicist interested in relativity theory, quantum mechanics, and cosmology. He had translated Hermann Weyl's famous book Raum, Zeit, Materie (1st edition 1918) into French already in 1922 (with R. Leroy) and was a prolific author who had mastered the Levi-Civita tensor calculus fairly early in his career (in Paris). Born and brought up in the Canton of Neuchâtel, he became a full professor at the University of Lausanne in 1928. We have a long letter by him written to de Rham (dated 8 January 1931) when the latter was in Göttingen; it shows him in a very interesting light, philosophically and mathematically and discloses him as someone much concerned with the political events of the world. Thus in an end paragraph (referring no doubt to the popular unrest in Berlin of the period) he writes "Reverrons-nous la guerre? C'est un peu mon obsession." The letter indicates elsewhere de Rham's collaboration with Juvet in the latter's teaching activities; de Rham had become an assistant to Dumas in 1925 (at a salary of 200 francs per month) and in the summer of 1926 he had a teaching position at the local Collège classique. However, with encouragement from $\mathrm{Du}-$ mas, de Rham decided to turn to do research in topology, a field he knew was not much cultivated at the time. Courageously, he left for Paris where he spent two periods of 7 months each between 1926 and 1928, apparently with no stipend or scholarship to sustain himself, except his personal savings. As he writes in [2], one could live easily on 100 Swiss francs a month, and a payment of 100 French francs at the Sorbonne (equivalent to 10 Swiss francs at the exchange rate of the time) permitted him to matriculate there and follow any of the courses offered; he mentions the presence of Hadamard and Lebesgue at the Collège de France and that of Élie Cartan, Vessiot, Julia, Denjoy, Émile Picard etc. at the Sorbonne. Despite the eternal difficulty of obtaining books at the Sorbonne library (a situation which does not seem to have improved very much at most French universities), de Rham managed to read the principal memoirs of Brouwer (cited in Kerékjártó's 1923 book on topology (in German)) and a note of J.W. Alexander (Note on two three-dimensional manifolds with the same group in Trans. Amer. Math. Soc. 20 (1919), 339-342) as well as all works on topology he could find (we are citing de Rham here almost literally). We continue with de Rham's own narrative; no one seemed interested in topology at this time in Paris; Lebesgue had indeed given a course on topology at the Collège de France the year before. In fact, Lebesgue's courses during the previous years were: (1922-1923) Sur quelques questions d'Analysis Situs, à propos des travaux de Camille Jordan; (1923-1924) Sur l'Analysis Situs; (1924-1925) Les divers ordres de connexion des espaces supérieurs (cf. pp. 177-179 in [9], vol. 1). Indeed, all these courses were on topology; but in 1925-1926 and 1926-1927 Lebesgue had switched entirely to analytical themes: Quelques procédés récents d'intégration (totalisation de M. Denjoy, intégrales de Radon, Hellinger, etc.... and Sur la fonction $\Gamma$ et quelques relations fonctionnelles. Nevertheless, Lebesgue was of great help to de Rham during his stay in Paris; not only did he give de Rham much useful bibliographical and mathematical advice, he also helped him to publish his first article Sur la dualité en Analyis Situs in the Comptes Rendus (1928, item [1] of [1]). De Rham remained grateful to Lebesgue all his life; in all 
our conversations with him concerning Lebesgue, he expressed great admiration for the man and his work. Thus it did not surprise us to see him going to great pains in order to publish the works of Lebesgue (in 5 volumes, produced by l'Enseignement Mathématique over the years 1972-1973); although de Rham's name does not appear anywhere in these 5 volumes and the "avant-propos" was signed by François Châtelet and Gustave Choquet, it was clear to us that the spirit of de Rham was strongly backing the whole enterprise. We clearly recall his organization of the presentation of these volumes in Geneva in the presence of Jacques Lebesgue (Lebesgue's son), Gustave Choquet, Marc Kac and many others, followed by a sumptuous dinner to celebrate the occasion, one of his many endearing rituals for marking such events.

To continue our narrative (following de Rham [2]), in autumn 1928, after his return to Lausanne to teach ("comme il faut gagner sa vie") at the Collège and the Gymnase, de Rham discovers Élie Cartan's note Sur les nombres de Betti des espaces de groupes clos in the Comptes Rendus subscribed to by the library of the École d'Ingénieurs (the future EPFL); as de Rham writes: "Cette note met mon cerveau en ébullition et le lendemain je suis sûr d'avoir la solution de ces problèmes". This then is the moment of discovery of the famous de Rham cohomology theory - although such a terminology would have been unthinkable in 1928. Now comes the final run for de Rham's thesis; de Rham writes to Lebesgue, eventually the latter is convinced enough to have another Comptes Rendus note published in July 1929 (item [2] of [1]) and finally, in April 1930, de Rham produces the complete text of his thesis for Lebesgue, who immediately sends him to Élie Cartan for consultation. All goes well and, eventually, Lebesgue helps de Rham to publish his thesis in Journal de mathématiques pures et appliquées (also known popularly as Journal de Liouville), vol. 10 (1931), pp. 115-200 (item [3] in [1]); finally, de Rham defends his thesis before an examination commission formed of Cartan (president), Montel and Julia. The thesis is dedicated to "Monsieur Henri Lebesgue, Hommage très respectueux". Thus is accomplished the first step in an illustrious career; as indicated before, de Rahm had spent, in between, four months in 1930-1931 in Göttingen, meeting many important mathematicians, some still in their formative period, like Charles Ehresmann, Edmund Landau, Hermann Weyl, Richard Courant, Emmy Noether, Gustav Herglotz, Pavel Aleksandrov, Andrey Kolmogorov among others.

Much of the rest of our narrative is based on de Rham's correspondence and related documentation. But before we go on with this, we must briefly outline de Rahm's mathematics.

\section{De Rham's Mathematics}

De Rham's collected papers [1] give the best overview of his mathematical work. It is not possible for us to give a detailed survey of all of it; we shall simply point out some salient features. De Rham's thesis of 1931, entitled
Sur l'Analysis Situs des Variétés à $n$ dimensions (item [3] of [1]) forms the foundation of much of his later work. The thesis itself is divided into four chapters; the first gives a good summary with improvements of the theory of finite complexes and their homology; the second chapter discusses intersection theory of chains in a complex; the third chapter introduces the use of multiple integrals over chains in an $n$-dimensional variety using as integrands differential forms, and the fourth chapter gives several examples of complexes which have the same Betti numbers and the same torsion, but are not equivalent. This last was inspired by the desire to generalize some results of Alexander and later gave rise to much work by de Rham and independently by Reidemeister and by Franz discussing various "lens spaces" which are or are not homeomorphic despite having the same homology groups and fundamental groups. The third chapter eventually led to a general cohomology theory (which came into the fore-front only after 1935) using differential forms and Schwartz's later theory (1945) of distributions which permitted de Rham to develop his elegant theory of currents. One way of viewing lens spaces is to consider them as the quotient spaces of spheres modulo certain finite groups of rotations. This induced de Rham to introduce an apparently simple problem at a 1935 meeting of topologists at Moscow, organized by Pavel Aleksandrov and attended by several luminaries like Heinz Hopf, Witold Hurewicz, Jacob Nielsen, André Weil, Hassler Whitney and others. The problem he proposed (in item [8] of [1]) is the following: Two tranformations $T_{1}, T_{2}$ of a variety $V$ into itself are called homeomorphic if there exists a homeomorphism $S$ of $V$ such that $T_{2}=S^{-1} T_{1} S$; when are two rotations $T_{1}, T_{2}$ of an $n$-dimensional sphere $S^{n}$ homeomorphic? If the rotations $T_{1}, T_{2}$ have the same eigenvalues (as linear endomorphisms of $\mathbb{R}^{n+1}$ ) then obviously they are homeomorphic (choosing $S$ itself to be a suitable rotation); the converse statement that homeomorphic rotations have the same eigenvalues turns out to be very difficult to settle. We summarize here the positive result obtained by de Rham and the surprising negative result obtained by Cappel and Shaneson much later. By 1964, de Rham had proved that two diffeomorphic rotations (i.e. $S$ is to be a diffeomorphism) have the same eigenvalues; this was a major result, on which de Rham must have spent a lot of effort; the final result appears in item [44] of [1] and there are several instructive previous and subsequent papers on this theme. However, in his final paper (a survey of this problem) in 1981, de Rham announced that Cappel and Shaneson in 1979 had shown that there exist homeomorphic rotations of $S^{9}$ which do not have the same eigenvalues. The long paper that Cappel and Shaneson wrote on this problem (and its vast generalizations) in the Annals of Mathematics (vol. 113, 1981) shows the extreme subtlety of the subject. For further information one should consult item [61] of the collected works [1].

It is interesting to observe here the great changes in the nature of topological studies between the time when de Rham was writing his thesis (1931) and the time (1981) when he was composing his last article. This is borne out 
dramatically by de Rham's bibliography of 1931 which consisted of items which very few would know today; thus de Rham refers specially to a long memoir (in Spanish) by $\mathrm{H}$. Weyl as being his inspiration for the composition of chapter 1 (on the general theory of complexes). This reference (dating from 1923) was suggested to him by Lebesgue; a reading of de Rham's reminiscences in item [60] of [1] is specially interesting in this and matters related to the writing of his thesis.

Soon after his thesis, de Rham discovered that his work permitted a generalization and simplification of some work of W.V.D. Hodge from 1930. This led to an interesting exchange of influences at a distance between Hodge and de Rham. As described by de Rham, Hodge used the latter's work to define and study harmonic forms, which in turn led de Rham to one of his famous papers on harmonic differential forms (written with Bidal, published in 1946/1947, cf. item [14] in [1]) containing new definitions and proofs. This work in turn led Hodge (and later A. Weil) to their studies on Kähler manifolds. Kodaira had travelled a similar route by entirely independent methods. Needless to say, all this would need much explanation to expose in a meaningful way. We shall comment on Bidal's work with de Rham later.

De Rham mastered the new Schwartz distribution theory very rapidly; no sooner was the first paper in this area published by Schwartz (in 1945) that de Rham gave lectures on it (in January 1947) to the Cercle Mathématique in Lausanne (about which, later). Of course, he saw immediately how distribution theory would place his own theory of currents on an elegant general basis (see document $\mathbf{6}$, letter dated 7 January 1947 of de Rham to Schwartz explaining this very clearly and document 7, Schwartz's reply of 3 Febrary 1947). With his mastery of the theory of differential forms adjoined to distribution theory, de Rham was now in a position to work on general theorems on partial differential equations (cf. items [28], [29], [34], [40] of [1]). His student Methée (whom we have already mentioned) wrote his thesis on Lorentz invariant distributions in 1953.

We shall only barely mention de Rham's important paper on Riemannian manifolds (published 1952) which, among other things, gives a new proof of the Hopf-Rinow theorem on complete Riemannian manifolds. There is, of course, much more. But we shall now indicate another entirely different aspect of de Rham's research, which led him to some very interesting results of real analysis. We shall illustrate this by citing one fine theorem (from item [27] in [1], published in 1953). The problem posed is that of determining a bounded function $f:[0,1] \rightarrow \mathbb{C}$ such that

$$
f\left(\frac{t}{2}\right)=\alpha f(t), \quad f\left(\frac{1+t}{2}\right)=\alpha+(1-\alpha) f(t)
$$

where $\alpha \in \mathbb{C}$ with $|\alpha|<1$ and $|1-\alpha|<1$. Then, such a function is uniquely determined and is continuous. If $|\alpha|>$ $1 / 2$ and $|1-\alpha|>1 / 2$ ( $\alpha$ is then necessarily complex) then $f=u+i v$ with $u, v$ real continuous functions which are nondifferentiable everywhere. Finally, if $\alpha$ is real and $\neq$
$1 / 2$, then $f$ is real, strictly increasing, with $f^{\prime}(t)=0$ almost everywhere.

We find that the beauty of this theorem is that in one stroke, de Rham obtains, effortlessly, the so-called "singular functions" of real variable theory. De Rham wrote several other papers in this vein, generalizing the constructions and giving probabilistic and geometric interpretations for many of them. Of course, this area is a welltrodden territory and naturally de Rham received a lot of correspondence on these matters, not only from old masters like Denjoy and P. Lévy, but also from several younger enthusiasts.

\section{De Rham's Career}

Soon after his thesis in 1931, already in 1932 de Rham acquired a teaching position at the University of Lausanne (chargé de cours with the title of privat-docent). After the premature death of Juvet, de Rham essentially became his successor, first as professeur extraordinaire (from April 1936) and then, from 1943 onwards, as full professor (professeur ordinaire). He also held similar positions simultaneously at the University of Geneva (from 1936 onwards); although he continued to live in Lausanne, he managed to maintain a vigorous teaching and other activities at both universities. By the end of the 1930's, de Rham had obviously become a major personality in the mathematical world of Swiss Romande as well as nationally. From 1932 onwards, de Rham, Juvet and Jules Marchand (1888-1953, professeur extraordinaire 1928-1936, professeur ordinaire 1936-1953) became the organizers of the Cercle Mathématique, a very vigorous group originating with Dumas (as Colloque mathématique des Universités romandes since 1923). Space does not permit us to describe the Cercle in greater detail; it remained active until around the 1980's, organizing lectures by some of the most eminent mathematicians of the world. The three volumes of notes which we have inherited give a vivid survey of the Cercle's activities, summarizing (sometimes in great detail) the contents of the lectures given at its regular meetings. The members of the Cercle paid very nominal dues, the costs of travel etc. were covered (modestly) from various university funds. There were, of course, in parallel, the activities of the Swiss Mathematical Society (SMS) of which de Rham became a president during the troubled years of 1944-1945, having been in the Committee (as has always been customary for that Society) since 1940 (first as secretary-treasurer for two years, then as vice-president for two years). We shall go into a few details later, regarding some events of the war-torn years of 1939-1945 and the immediate postwar period as evidenced by de Rham's abundant correspondence from these years.

To complete our brief sketch of de Rham's career, we mention his visiting appointments at Harvard University during the winter of 1949-1950, at the Institute for Advanced Study at Princeton in 1950 and again in 1957. These sojourns were obviously very fruitful to de Rham (as shown by his publications) and allowed him 
to confirm his friendship with such mathematicians as Whitney and Alexander, both of whom he had first met in Switzerland as eager mountaineers. His international renown had become well-established by the time of the publication of his book Variétés différentiables in 1955; it must have been written during 1952-1953 since the preface of the first edition is dated August, 1953 (Lausanne). As a young man, he had attended the ICM 1932 in Zurich, where he had presented a communication based on a part of his thesis; he must have been very pleased to hear his work being mentioned specially in Élie Cartan's invited address at the Congress entitled Les espaces riemanniens symétriques. Incidentally, Gustave Juvet (mentioned above) had presented a communication captioned Les nombres de Clifford et leurs applications à la physique mathématique. De Rham had also presented a communication at the first post-war ICM in 1950 at Cambridge, Mass. (USA) based on his recent work (title: Intégrales harmoniques et théorie des intersections); he also presented a paper at the next ICM 1954 at Amsterdam (title: La notion de valeur à la frontière pour un courant).

Skipping over various honours bestowed on him already since 1954, (e.g. doctorate honoris causa, University of Strasbourg) we mention his nomination as president of the International Mathematical Union (IMU) for the years 1963-1966 and, as such, his presence as president of the IMU at the ICM 1966 in Moscow. This only describes a very small part of his activities for the IMU; in a separate section, we shall describe the long association of Switzerland with IMU and ICM. De Rham's association with the IMU brought him inevitably in contact with $\mathrm{K}$. Chandrasekharan (about whom see below) who was then in a leading position at the Tata Institute of Fundamental Research (TIFR) at Bombay, India. This led to his visiting position at TIFR during the year 1966 where he wrote his Tata lecture notes in algebraic topology (which we have already mentioned above).

We must now mention de Rham's leading role in the creation of the Troisième Cycle Romand de Mathématiques in Autumn 1969, which played an important part in the development of mathematical activities in Swiss Romande; a complete report on this appears elsewhere in this volume. Suffice it to say here that his assiduous presence at the lectures of the Troisième Cycle (even after his retirement in 1971-1973) set up an example for his young colleagues. By this time, de Rham had built up an impressive mathematics department at the University of Geneva with the presence of leading mathematicians like André Haefliger (born 1929) and Michel Kervaire (1927-2007); a passing presence of a year or so in Geneva was that of Raghavan Narasimhan (born 1937) from TIFR who eventually settled down at the University of Chicago but has continued associating himself with many Swiss mathematical activities. A special mention in this context must be made of Armand Borel (1923-2003); born in La-Chaux-de-Fonds (Neuchâtel), he was well-known to de Rham and his colleagues and had exerted considerable influence on Swiss mathematics during many years. Borel's meteoric career led him from ETH to Princeton and back again to ETH and Princeton (amongst many other places). Although his actual professional career in Switzerland was not long, through his personal association (and regular visits to Lausanne) he continued to influence Swiss mathematics.

We omit de Rham's activities at various national commissions and his essential influence in associating Switzerland with the creation of the IHES (Institut des Hautes Études Scientifiques) near Paris. A long list of the various honours bestowed on him can be found in [1]. We close with some remarks about two areas where de Rham did not take any active part. The first is in the activities of the Euler Commission; the work here being of a historical nature this is understandable. After all, no one can do everything. A more glaring omission is his absence in the formation of EPFL, which was after all an emanation of the École d'Ingénieurs of the University of Lausanne. This may have several explanations. De Rham was not specially interested in the so-called applied mathematics and the creation of the Mathematics Department of the EPFL was based on separating "pure mathematics" which was to remain at the University and the "applied" to be developed at the EPFL. There may have been personal differences of opinion. A mathematician whose name should be mentioned here in this context is that of Charles Blanc (1910-2006) who was a younger colleague of de Rham for many years at the University of Lausanne. Although he had started with a thesis at the Sorbonne in 1937 in pure mathematics (Riemann surfaces) he had turned to engineering applications rather early in his career. He was a pioneer in the introduction of computers in Lausanne and strongly encouraged the development of fields like Operations Research, Numerical Analysis and Informatics. A full account of this mathematician of the de Rham era is given elsewhere in this volume. Suffice it to say that he was a chargé de cours (1936-1942), professeur extraordinaire (1942-1949), professeur ordinaire (1949-1969) at the University of Lausanne, after which, he continued his professorship at the EPFL from 1969 till his retirement in 1975. Blanc was very active in the publications of the Euler Commission of which he was the president during 1967-1975 and the editor of eight of the volumes of Euler's works on mechanics and astronomy (Series secunda of the Opera omnia containing 31 volumes, of which volumes 26, 27 are yet to be published - foreseen for 2010). There is of course much more to write on other mathematicians of the de Rham era and some will be mentioned later. Fortunately, the rather pathetic separation of pure and applied mathematics has ended in Lausanne; since approximately 2001 (officially since October 2003), there is only one Mathematics Department, based at the EPFL, combining all of the branches previously practised at either the University or the EPFL, and indeed expanding its domain of activities to keep pace with the progress of mathematics.

There is, of course, much more to be said about de Rham's career - about his teaching, about his research students and collaborators, about his editorial activities, 
etc. Concerning the last point, we just underline his editorship (along with Albert Pfluger and Johann Jakob Burckhardt) during 16 years (1950-1966) of the Commentarii Mathematici Helvetici, a journal founded by the SMS in 1928; Pfluger (1907-1993) was a professor at the ETH and Burckhardt (1903-2006) was at the University of Zurich (see [4]); the latter has written a short account of de Rham's editorship of the Commentarii in [2]. Between 1967-1978, de Rham acted as an editor of L'Enseignement Mathématique, which can be described as the mathematical journal produced by the University of Geneva, although its editorial board has always had the collaboration of many mathematicians from different parts of the world. It was founded in 1899 by Henri Fehr (1870-1954), professor at the Unversity of Geneva and Charles-Ange Laisant (1841-1920), associated with the École Polytechnique of Paris. It has served as the official organ of the Commission internationale de l'enseignement mathématique over many years. In recent years, its articles have been directed more to research mathematicians, albeit with some emphasis towards exposition and avoidance of overly specialized research. Its early numbers offer a fascinating glimpse of the development of mathematics during the early years of the 20th century as well as containing much historical information about mathematics and mathematicians.

\section{De Rham's Correspondence}

We have found the remains of de Rham's far-flung correspondence spread over the years 1935-1972 and many letters from later years (up to approximatively 1984). We have already mentioned the single letter (in our possession) of Juvet dated January 1931. We also have several of de Rham's letters to others, either as carbon copies or rough drafts. Many letters are essentially of a bureaucratic nature (like letters from various University or Government officials, letters of invitation for varied meetings or those inviting de Rham to lecture at different places, or merely administrative documents) or letters to mountaineering acquaintances or some family letters. However, there is a substantial number of a purely (or mostly) mathematical character. The correspondents include some of the most eminent mathematicians of the period and it would be a tiresome task to make a complete enumeration. We shall therefore give a selection of those which we have found most interesting in one way or another; they should give an idea of the mathematical and political climate, specially for the period 1935-1947.

The most assiduous correspondent (over the years 1935-1951) was André Weil (1906-1998). Weil's first letter was from Strasbourg in 1935; his later letters were increasingly mathematical, full of ideas and questions related to de Rham's work. The fearful period 1940-1945 seemed to find Weil in a most creative and exuberant form. We have reproduced (document 3 ) his letter dated June 5, 1940, composed after his well-known adventure in Finland in 1939, landing in a jail there (suspected of being a spy), from where he returned to France to be jailed there for a few months in 1940 (for evading military service), all of which Weil later described with gusto in his autobiographical Souvenirs d'apprentissage (Birkhäuser, 1991). He was eventually released and incorporated in the French army in May 1940; this explains the tone of his letter to de Rham, which is almost jovial. His buoyancy is partly explained by his spectacularly successful mathematical activity during the period 1939-1940, some of which is described briefly in the letter itself. It is also interesting to read his plans for introducing integrals of differential forms by a suitable extension of his (and Bourbaki's) theory of Radon measures. As is well-known, after the collapse of the French army in mid-June 1940, the army disbanded and Weil managed to get to England in July and thence (after various meanderings described in his autobiography) he finally arrived in New-York (with wife and family) by March 3rd, 1941. We shall not repeat here his further story in America, thence to São Paulo in Brazil, finally ending up at Chicago in the autumn of 1947 and from there settling down at the Institute for Advanced Study in Princeton (from 1958 until his death). What is interesting to note here is that he wrote several long letters to de Rham from S. Paulo and from Chicago describing his own work and taking keen interest in de Rahm's work with Bidal (1946-1947); de Rham's replies are also fairly detailed. A reproduction of their exchange of letters with a careful study of their contents will need a small booklet. We remark in passing that during the period 1940-1946, Weil managed to write his books L'intégration dans les groupes topologiques et ses applications (1940) and Foundations of algebraic geometry (1946) as well as several important papers on varying subjects, carrying on vigorously his work for Bourbaki as well (cf. Weil's three volumes of Collected Papers, Springer, 1978).

Backtracking a little, we consider briefly some correspondence of mathematical importance with Kurt Werner Friedrich Reidemeister (1893-1971) and Wolfgang Franz (1905-1996). Reidemeister's letter from Marburg (dated 10 April 1935) informs de Rham of his complete solution of the homeomorphy problem for 3-dimensional lens spaces (by using the so-called Reidemeister invariants, a term de Rham used in the title of his 1935 conference in Moscow, item [8] of [1]); Franz had indicated in his letter (of 20 June1935) a complete solution in higher dimensions and de Rham mentions both these facts in his above-mentioned paper given at Moscow, indicating that he had an independent proof of Franz's theorem. Let us recall that Reidemeister had been forced to move to Marburg in 1933 (from Königsberg) because of his conflict with the Nazi student demonstrators (Hitler had been appointed Reichskanzler on 30th January 1933 by President Hindenburg); Reidemeister, however, maintained his full professorship in Marburg, where Franz was his assistant and where Franz obtained his Habilitation in 1936, moving on eventually to the University of Frankfurt where he retired in 1974. De Rham seems to have remained in contact with Franz for many years subsequently, both mathematically and otherwise. Several of de Rham's later papers refer to Franz's work while he was generalizing it to 
his theory of "complexes with automorphisms", a subject to which de Rahm devoted several papers (e.g. items [11], [22], [49], [50], [51] in [1]). The subject of ReidemeisterFranz-Whitehead (J.H.C.)-torsion seems to have grown in importance, if we follow the 2001 report of Andrew Ranicki, since it allows a finer classification of spaces than that given by homology and other invariants.

In January 1938, de Rham gave lectures at Hamburg (Über mehrfache Integrale) on the invitation of Blaschke; this is the only paper in German in his CEuvres (item [10] of [1]). Then in September 1938, he was invited to lecture at a German Physics-Mathematics meeting (Deutscher Physiker-und Mathematikertag). His talk Sur un procédé de formation d'invariants intégraux was published (and given) in French in the Jahresbericht der Deutschen Mathematiker-Vereinigung in 1939 (item [12] of [1]). Invited to become a member of the German Mathematical Society (Deutsche Mathematiker-Vereinigung, DMV) he did so in 1938; according to DMV records, he did not renew his membership afterwards. He was again invited to attend a meeting in Münster in July 1939; this however he declined (for reasons of health). Recall that 1938 was the year of Munich (29th September), the Anschluss (12th March) and the Kristallnacht (10th November), amongst other things; by 1st September 1939, the German army had crossed into Poland and by 3rd September 1939 Britain and France had declared war. Of course, since the accession of the Nazis to power in 1933, many terrible things were happening in Europe; curiously, the correspondence received by de Rham leaves hardly any echo of any of this. There is a pathetic circular letter from Arthur Rosenthal's old mother (dated 4 December 1938) stating that her son was in Dachau and asking for help; Rosenthal (1887-1959), who was a full professor at Heidelberg (since 1930, specializing in measure theory and real variables) somehow escaped to the USA by 1940 and ended up as a full professor at Purdue University.

While all of these terrible things were happening (not just in Europe but elsewhere also) what impresses us is the desire of the mathematicians to continue with their mathematical research. In 1939, the Jubilé scientifique of Élie Cartan was being organized, de Rham being one of the invited persons. In June 1939 a Convegno Volta was organized by Francesco Severi in Rome for 22-28 October 1939 and de Rham received an invitation to participate, in a letter signed by Severi and Luigi Federzoni, once the fascist minister of interior and now Presidente della Reale Accademia d'Italia. ${ }^{2}$ We have seen documents which prove that de Rham's invitation had been allowed only after a preliminary verification that he was neither Jewish nor anti-fascist. De Rham had accepted to attend the meeting (with his sister) which was however cancelled officially by a letter dated 21 September 1939 (signed by F. Severi) "on account of the prevailing international situation".

We shall at this point refer to his extensive correspondence with Béla Kerékjártó (1898-1946), the Hungarian mathematician from whose topology book (of 1923) de

${ }^{2}$ and Cavaliere dell'Ordine Supremo della Santissima Annunziata.
Rham had acquired much useful information while preparing his thesis (in 1926-1930); the correspondence starts in 1937 and continues through to 1946 when Kerékjártó died of ill health resulting, it seems, from lack of suitable medical care. De Rham had visited Kerékjártó in May 1940 (giving a lecture in Budapest) and had tried his best to help the latter by inviting him to come to Geneva (with his ailing daughter) in 1945-1946, offering him through the University authorities in Geneva comfortable conditions of staying there for a while. In general, the Swiss mathematicians tried to do whatever they could to help their colleagues elsewhere as is shown by several circulars and letters which we have. For example, Sophie (Alice Caroline) Piccard (1904-1990) from the University of Neuchâtel (she had done her thesis in Lausanne in 1929 under Mirimanoff and was herself of Russian origin) wrote several letters in 1940 and later to de Rham indicating the need to help certain mathematicians in Poland; there is an interesting circular letter from Rolin Wavre (1894-1949, professor at the University of Geneva), dated 24th January 1940, sent to Piccard, de Rham and Hopf, agreeing with their desire to help colleagues, but pointing out the need for some circumspection due to the prevailing political situation. We recall that, by 1940, the Fascist regime was strongly in power in Italy, as were the Nazis in Germany, and Franco's total victory in Spain (with the help of Italy and Germany) over the republicans there was an accomplished fact. As it turned out, by July 1940, France had fallen (divided for the time being into an occupied zone and a zone where the Vichy collaborationist regime reigned supreme) as had many other small countries in Europe (Belgium, Holland, Denmark, Norway). The feeling of being surrounded by hostile powers was therefore a perfectly natural one, specially for those living in areas like Geneva, Lausanne, Basel, Zurich or Neuchâtel within a stone's throw from alien territories occupied by bellicose forces. What is remarkable though, is that much mathematical cooperation continued in a very fruitful way as shown in the de Rham correspondence of the period. Thus de Rham himself visited Clermont-Ferrand in November 1940 and again in autumn 1942; many of his French mathematical friends were there, having moved from occupied Strasbourg and Nancy (e.g. Henri and Élie Cartan, Charles Ehresmann, Jean Dieudonné, André Lichnerowicz..., cf. Schwartz's autobiography Un mathématicien aux prises avec le siècle, Odile Jacob, 1997, page 155). In 1940, de Rham may have met both Schwartz and Feldbau at Clermont-Ferrand; Feldbau's letter to de Rham (dated 21 November 1940, document 2) is interesting. Jacques Feldbau (1914-1945) was a student of Ehresmann whose promising mathematical career ended in a concentration camp (cf. Schwartz's autobiography cited above); nevertheless, Feldbau managed to publish several papers (some under the pseudonym Jacques Laboureur, one jointly with Ehresmann) in the theory of fibre bundles which was in its infancy then (cf. Steenrod's account of the Ehresmann-Feldbau work in N. Steenrod's book The topology of fibre bundles, Princeton University Press, 1951). We may mention here that in de Rham's mathematical unpublished papers there are some ten pages of 
an attempt for the development of a theory of fibre spaces; the pages are dated 1939 and this was later somewhat elaborated, but none of this seems to be at a publishable stage.

A very interesting fact, described in detail in Schwartz's autobiography (mentioned above, cf. pp. 238240), concerns de Rham's 1942 visit to Clermont-Ferrand when the latter lectured on a tentative theory of courants (not yet named as such); at this point, Schwartz had not yet worked on his own distribution theory. Schwartz remarks that during a conversation with de Rham they speculated on a possible extension of the theory when de Rham apparently said "Ce n'est pas pour nous, ce sera pour la prochaine génération". As we know, things moved much more rapidly; Schwartz's distribution theory was ready in 1944-1945 and de Rham had already worked out his theory of courants by 1947 (see documents 6, 7).

At this point, we may mention Ehresmann's considerable exchange of letters with de Rham; their acquaintance went back to their stay in Göttingen in 1930-1931 and this seems to have developed into a friendship with considerable mutual esteem. We have reproduced (document 5) a letter of Ehresmann (dated January 3, 1946) which, besides being interesting in itself for the light it throws on the events in France during 1940-1945, gives an indication of their friendship. We may note that de Rham later recommended one of his best students, André Haefliger, to go and do his doctoral work with Ehresmann in 1954 at the University of Strasbourg (cf. Haefliger's account of this in [2], pp. 69-72). The collected works of Ehresmann (1905-1979) were published in 1983 in Cahiers de Topologie et Géométrie Différentielle, a journal Ehresmann had founded around 1958.

We return to our theme of mathematicians meeting each other in the midst of a world-wide war. De Rham himself undertook some hazardous trips. One of the most dangerous seems to have been his trip to lecture at the University of Munich on 28th January 1944 at the invitation of Georg Faber (1877-1966). The bureaucratic arrangements to obtain the permission to travel between Lausanne and Munich were indeed very complicated; in one long form filled out by de Rham (for the German authorities) he had to spell out his religious affiliation as "Protestant" and declare himself as "Nicht Juder". Finally, for reasons not clear to us, de Rham travelled accompanied by the physics professor from Lausanne Ernst Stückelberg von Breidenbach (1905-1984), belonging to an aristocratic family of Basel (Baron Souverain du Saint Empire) who did some distinguished work in theoretical physics. They arrived in $\mathrm{Mu}-$ nich on the evening of 26 January 1944 and were met by Carathéodory at the station. De Rham's lecture was entitled Sur les formes différentielles harmoniques dans un espace de Riemann. Faber then thanked de Rham by a letter dated 7 February 1944 for his visit and for the reprints he had been given. All this in the midst of a very heavy bombing campaign of the allies in various parts of Germany!

A more curious meeting (to which finally de Rham did not go) was organized by F. Severi (1879-1952) for the beginning of November 1942 (Convegno internazionale di matematica). In his letter of invitation (dated 7 October 1942) Severi indicated that only the participation of mathematicians of Belgio, Bulgaria, Croazia, Germania, Italia, Norvegia, Romania, Spagna, Svizzera, Ungheria was planned. Heinz Hopf in Zurich was also invited; Hopf (who had excellent contacts with de Rham; more on this later) asked de Rham in a letter dated 18 October 1942 whether de Rham was planning to attend and that he himself had refused, giving the excuse of overwork. Recall that, at this time, Italy had been at war against France and that the Mussolini government had already passed in September 1938 its racial laws which essentially excluded its most eminent scientists (like Levi-Civita, Enriques, Castelnuovo, Fubini, Volterra, ...) from association with research and teaching in Italy (cf. the book by G. Israel and P. Nastasi Scienza e razza nell'Italia fascista, il Mulino, Bologna, 1998). We shall see later that Hopf knew perfectly well the dangers for any one of Jewish origin of travelling in such countries with racial laws. De Rham however had been to Rome on a visit during the spring of 1942 which apparently had been quite agreeable; in any case, he wrote a formal letter to "Son Excellence le Président de la Réunion Volta" on 23 October 1942, indicating his impossibility to participate due to overwork.

De Rham seemed to be fairly unconcerned about political matters; this came out rather clearly when Enrico Bompiani (1889-1975) was invited to lecture to mathematicians in Lausanne without the latter being consulted about the visit at all. De Rham's colleague Marchand (whom we have already mentioned before) seemed to have been more sensitive to such issues; we do not know of Marchand's political feelings; however he took much exception to the fact that Bompiani was being parachuted on the Cercle Mathématique of Lausanne through a direct invitation of the Istituto Italiano di Cultura, Losanna, with the complicity of the University authorities. Recall that Bompiani (like Severi) was an active member of the Fascist party in Italy and their actions, after the establishment of the racial laws in Italy, were not glorious. Marchand may also have recalled the conferring by the University of Lausanne of a doctorate honoris causa in 1937 to Benito Mussolini, at a time when the fascist dictator was carrying on actively in the Spanish Civil War and had already accomplished his bravura attacks on Ethiopia in 1935. To the great credit of the later University of Lausanne, the Rector of the University (in 1987) instigated a very thorough study of the whole episode for the 450th anniversary of the Academy in Lausanne. A book written on the subject is by Jean-Christian Lambelet Des palmes académiques pour Benito Mussolini, L'Age d'Homme, Lausanne, 2004.

The Swiss mathematicians on their side organized various encounters with their French colleagues as much as was possible. An important one was organized by the Cercle Mathématique on 25 October 1942 with the participation of Lichnerowicz, Brelot, Ehresmann, Ferrand, Malécot (amongst the French). The organization was not a minor task, given the difficulties of the times; de Rham took full part in this. 
There is, of course, much more, even during the years 1935-1945; for example, interesting mathematical correspondence with Heinz Hopf and his student Eduard Stiefel, letters exchanged with Siegel concerning the work of one of de Rham's promising students Pierre Humbert (1913-1941) whose unexpected death obliged de Rham to see to it that his important work on algebraic number theory was finally published. The death of Humbert induced the mathematicians in Lausanne to invite Beno Eckmann (1917-2008), then a young and very promising student of Hopf to come and join the Faculty in Lausanne over the period 1942-1948; unfortunately for the mathematicians in Lausanne, Eckmann was offered a professorship at the ETH in 1948 where he continued to do brilliant research in the most varied fields of mathematics (topology, geometry, algebra, complex manifolds, etc.), producing perhaps the largest number of successful students who went on to occupy professorial positions in several universities of Switzerland and all over the world. It would take much more space to develop Eckmann's career (as well as that of the eminent mathematician E. Stiefel mentioned above) but fortunately in [4] there is much valuable information on this score.

The correspondence from the post-war period is, as is to be expected, of a much more undramatic nature (except for two incidents which we prefer to develop separately). There are long letters from young mathematicians like Georges Vincent (1916-1999) and André Delessert (born 1923) on mathematical matters - both of whom became professors at the University of Lausanne. There are many letters to and from Haefliger, de Rham trying to enrol him for Geneva, letters from Kervaire and so on. As light diversion, let us cite a letter from Hermann Weyl (July 1954) who was to report on Kodaira's (Fields Medal winning) work at the ICM 1954 in Amsterdam; Weyl writes "[this] causes me considerable headache since I know nothing of algebraic geometry nor of faisceaux". There are long letters from Serre (March 1954) concerning complex manifolds and the use of faisceaux, and de Rahm's detailed reply along with related correspondence with $\mathrm{H}$. Cartan. There is a very technical (somewhat long) letter to Harishchandra concerning the calculation of some constants in the fundamental solution of the hyperbolic equation

$$
\left(D_{1}^{2}+\cdots+D_{p}^{2}-D_{p+1}^{2}-\cdots-D_{p+q}^{2}\right) f=\delta
$$

related to de Rham's paper item [40] in [1]; this correspondence continued in 1959.

There is a letter from Herbert Seifert (1907-1996) dated 5 August 1949, informing de Rham of the death of William Threlfall (1888-1949); de Rham had met both Seifert and Threlfall during his visit to Baden-Baden in 1938 at the DMV meeting mentioned before. During the difficult post-war years, de Rham had organized much help for Threlfall and later to Seifert.

A post-card (document 8) from Erich Kähler's mother is interesting: it requests de Rham to send his reprints on Hodge Theory (more or less exact references are given; these are items [14] and [16] of [1]) to her son who was then in a prison camp in France. Erich Kähler (1906-2000) eventually became a full professor at Hamburg; his collected works were published in 2003 by Walter de Gruyter.

We feel that we have given some idea of the flavour of the immediate post-war correspondence; a complete coverage of the later period would require much more space and effort. Instead, we now turn to two isolated episodes from the period 1945-1947 which merit some clarification.

\section{The Case Bidal}

In a long letter from São Paulo (dated 26 Sept. 1946) Weil writes at length to de Rham on the latter's work on Hodge Theory (with Bidal) and amongst other things, mentions Kähler's Prison Camp address in France (see above Kähler's mother's post-card to de Rham). He then gives his own ideas on the subject, complimenting de Rham warmly on his work and essentially encouraging the latter not to waste any time on teaching and even to go to a foreign country to achieve this. At the end of the long type-written letter, Weil adds (by hand) "P.S. Qui est Bidal?". On 19 October 1946, de Rham gives a detailed (type-written) reply containing various mathematical ideas. At the end, he explains that the paper written with Bidal is, in fact, a thesis which Bidal had written under his (de Rham's) direction but that, in order to finish it, de Rham had to undertake the complete redaction. This seems to us as the true state of affairs, stated as briefly as possible. Since many rumours had circulated about the matter, we feel that a further clarification seems useful now.

Pierre Bidal (1914-1964) had done a licence ès sciences mathématiques in 1937 at the University of Lausanne; this is according to Bidal's brief biography in [6], page 595; according to de Rham's report of 16 Dec. 1945 to members of the Jury for Bidal's thesis, MM. Ch. Blanc and B. Eckmann, Bidal's Licence was from Autumn 1936; this is a very minor difference. Bidal then proceeded to work for 3 years on mathematical physics, learning integral equations, tensor calculus and other matters with great zeal while at the same time holding a teaching position at the Collège of Aigle. All of this and what follows is taken from de Rham's report. In 1940, Bidal approached de Rham for advice, looking for a thesis topic to be guided by de Rham. The latter proposed to Bidal the study of the harmonic differential forms of Hodge. In particular, de Rham asked Bidal to extend Fredholm's theorems to integral equations involving differential forms; Hodge's treatment of this was lacunary and hence needed amendment. Summarizing de Rham's report at this point, we may say that despite much effort on Bidal's part in clarifying the problem, Bidal did not succeed and de Rham took over the whole matter in his own hands and worked out a complete theory; de Rham's conclusion was that the problem was ill-suited for Bidal's capacity but that seeing the amount of labour invested by Bidal and the fact that Bidal's vain attempt had finally led de Rham to a solution, he proposed to the Jury that 
Bidal be granted a doctorate. The Jury accepted this recommendation and Bidal defended his thesis on the 29th Dec. 1945. The joint paper (Bidal-de Rham, item [14] of [1]) supplemented by an explanatory Avant-Propos (not published in item [14], given here as document 4) was then used as Bidal's thesis. We have seen the rough draft of a letter of de Rham to Bidal (composed at the end of the year 1945, written as "un collègue et un ami". We cite some relevant passages:

Si votre soutenance n'a pas été tout à fait comme vous l'espériez, ni comme je l'espérais de mon côté, cela est dû en effet en grande partie, me semble-t-il, à une erreur pédagogique de ma part. Je m'étais bien rendu compte que le sujet de votre thèse était trop difficile pour exiger que vous l'acheviez et c'est pour cela que j'ai terminé le travail ... Vous avez réussi et obtenu le doctorat, c'est l'essentiel et c'est seulement ça qui compte en définitive ... ne vous faites plus aucun souci, pas même pour l'avant-propos ... Quant à l'impression, comme je vous ai dit, je m'en occuperai.

We think that de Rham's gesture here is kind and noble. The relations between de Rham and Bidal remained friendly (as can be gauged from their short letters to each other and Bidal's continued presence at the Cercle Mathématique. Finally, in 1954, Bidal became a professeur au Cours de mathématiques spéciales (CMS as it has always been known here locally) at l'EPUL (the future EPFL). He continued to participate at the Cercle Mathématique and he himself gave a lecture in 1950. As far as we know, Bidal did not publish any further papers; he died in 1964.

\section{The Non-election of Hopf}

Heinz Hopf (1894-1971) came to the ETH in Zurich in 1931 as a successor of Hermann Weyl (cf. [4] for more details) and was undoubtedly one of the most outstanding and well-respected mathematicians of Switzerland during his life time. As is well-known, he was one of the major topologists of the 20th century and his book with P. Aleksandrov Topologie, Erster Band (no further volumes were published) in Springer-Verlag in 1935 remained for years a major reference in topology. He had many distinguished students (two of them, E. Stiefel and B. Eckmann, have already been named). It was thus natural that his contacts with the other eminent Swiss topologist, de Rham, were close and they met as often as occasion permitted, cf. de Rham's description of Hopf's work as presented in document 9 (unpublished). For our narrative, it is important to note that Hopf (and his wife) had become Swiss citizens by 26 June 1944. At the autumn 1947 session of the SMS (Swiss Mathematical Society) in Geneva, Hopf's candidacy for the presidency of SMS for the two year period 1948-1949 was refused, one of the reasons given being that Hopf was not born in Switzerland; there were other reasons as well (two of the three in the Committee would have been from the same University, namely ETH) but the last named reason upset a lot of people so that on 1st November 1947, a long letter of protestation signed by several leading Swiss mathematicians was sent to Fehr and Fueter. Then on 10th Nov. 1947, de Rham added his own personal voice regretting Hopf's non-election. This kind of squabbling was unusual for SMS elections and has remained so until today. The eminent mathematician from Bern, Hugo Hadwiger (1908-1981), was then proposed but Hadwiger refused his own election. Finally, after much polemical writing on different sides, they arrived at the following choice (in April 1948) for the Committee: Charles Blanc (president), A. Pfluger (vice-president), F. Fiala (secretary-treasurer). The whole discussion must have seemed very unpleasant to many and specially to Hopf who had undergone, in January 1939, a most disagreeable arrest and other humiliations at the hands of the Gestapo while on a visit to his parents (of Jewish origin) in Germany. This story had remained unknown until quite recently; thanks to a careful account presented by Urs Stammbach [10], we now are aware of this painful incident; the very discrete Hopf would probably not have told this to many, if any at all. Against this particular nonelection, we can record Hopf's election as the president of IMU for the years 1955-1958 (cf. next section).

\section{ICM, IMU and Switzerland}

Before we proceed, we must clarify the relationship between ICM (International Congress of Mathematicians) and IMU (International Mathematical Union). Without going into the complex history of the birth of the present IMU in detail, let us recall the essential facts (as authoritatively presented in Mathematics without borders by Olli Lehto, Springer, 1998; for further details this work is to be consulted and much of the present section is based on this book.)

What has been called the old IMU came into existence after the first world war in 1920 and survived until 1932. The foundation of the new IMU dates from 1952 after much preparatory work spread over the years 1945-1951. Whereas all the eleven ICM's (between 1897-1950) were essentially based on the efforts and policies of the corresponding local organizers, from 1954 onwards a decisive role has been played by the Executive Committee of the IMU as regards the choice of the site and that of the scientific content of the ICM's. Thus the first and the ninth Congress held in Zurich (in 1897 and in 1932 respectively) had to be based on Swiss organization and direction; on the other hand, for the 22nd Congress held in Zurich in 1994, all the scientific planning was in the hands of the IMU, although, naturally, the physical organization of the ICM was entirely the responsibility of the Swiss mathematicians. We note in passing that, so far, Switzerland has been the only country where the ICM has met thrice (in Zurich, in 1897, 1932 and 1994).

In the old IMU, W.H. Young (1863-1942), played an important part; although originally from Britain, Young had been living in Switzerland since 1909, and since 1915 he and his family (which included his wife G.C. Young (1868-1944), an active mathematician herself) were settled in the region of Lausanne. Young was a vicepresident of the IMU during 1920-1929 and president 
during 1929-1932. Young held no academic position in Switzerland although he participated regularly in the mathematical activities of the region. Young's friend, Henri Fehr, professor at the University of Geneva, (mentioned before as one of the founders of the Swiss Mathematical Society and of the journal L'Enseignement Mathématique) had the distinction of having attended all of the first eleven ICM's (held between 1897 to 1950), was a vice-president of the old IMU and very influential in the creation of the Commission on the Teaching of Mathematics which, under the acronym ICMI, has been a part of the IMU since 1952.

We have already mentioned K. Chandrasekharan (born 1920); well-known for his development of mathematical research at the Tata Institute of Fundamental Research, Bombay, he had become a full professor at the ETH in 1965, retiring from there in 1987; his association with the new IMU in numerous capacities over the years 1955-1978 is best described in the words of Lehto (see reference above) as follows: "for decades he was spiritus rector in the Union" (i.e. IMU); in particular, he was the president of the IMU during 1971-1974.

Other presidents of the IMU from Switzerland have been H. Hopf during 1955-1958, G. de Rham during 1963-1966 and Jürg Moser (1928-1999, professor at ETH since 1980) during 1983-1986. Besides these presidents, we must mention B. Eckmann who was a member of the Executive Committee of the IMU 1955-1962, secretary 1956-1961 and, amongst other associations with the IMU, honorary president of the ICM 1994 in Zurich. Further, A. Borel was a member of the Consultative Committee for the ICM 1966 in Moscow and Chairman of the same Committee of the ICM 1978 in Helsinki (Both Borel and Eckmann have been discussed above). The activities of several others in different Committees of the IMU or the ICM (such as Fields Medal, ICMI etc.) have not been listed. Let us recall that since 1950 the ICM has been organized every four years in varied locations and this has been one of the main tasks assigned to the IMU which has now taken up other activities as well in the promotion of mathematics internationally; the next ICM will be held in Hyderabad, India in August 2010 which, as has become customary, will be preceded by a meeting of the general assembly of all the members of the IMU in Bangalore, India. Switzerland will be represented by four delegates at the general assembly.

\section{Acknowledgements}

We thank Daniel Amiguet for his help with the history of de Rham's family and in the technical lay-out of the article. We are very grateful to Annalisa Capristo for providing us with little-known documents about the fascist period in Italy.

\section{References}

The bibliography has been kept to a strict minimum; several relevant references are to be found at the appropriate places of the essay. A preprint of Michèle Audin, Publier sous l'occupation I. Autour du cas de Jacques Feldbau et de l'Académie des Sciences gives considerable further information concerning Feldbau's work. For information concerning members of the German Mathematical Society (DMV) the publication Mitgliedergesamtverzeichnis der Deutschen Mathematiker-Vereinigung 1890-1990. Editor: Michael Toepell, München, 1991, will be found very useful. For facts concerning mathematicians in Germany and Austria who suffered under the Nazi rule, consult Mathematiker auf der Flucht von Hitler by Reinhard Siegmund-Schultze, Vieweg, 1998. An English updated version of this work was published in Princeton University Press in 2009.

[1] Georges de Rham, CEuvres mathématiques, L'Enseignement mathématique, Université de Genève, 1981.

[2] Daniel Bach, Oskar Burlet et Pierre de la Harpe (eds.), Georges de Rham, 1903-1990, Imprimerie Dupuis S.A., Le Brassus, 1995.

[3] Jean Dieudonné, A history of algebraic and differential topology, 1900-1960, Birkhäuser, Basel, 1989.

[4] Günther Frei und Urs Stammbach, Die Mathematik and den Zürcher Hochschulen, Birkhäuser, Basel, 1994.

[5] Pierre-Denis Methée, Les mathématiques à l'Académie et à la Faculté des Sciences de l'Université de Lausanne, Université de Lausanne, 1991.

[6] Maurice Cosandey (ed.), Histoire de l'École Polytechnique de Lausanne: 1953-1978, Presses Polytechniques et Universitaires Romandes, Lausanne, 1999.

[7] A la mémoire de Gustave Juvet (1896-1936), Université de Lausanne.

[8] Michel Plancherel, Mathématiques et mathématiciens en Suisse (1850-1950), L’Enseignement Mathématique ( $2^{e}$ série) 6 (1960) 194-218.

[9] Henri Lebesgue, CEuvres Scientifiques (5 vol.), L'Enseignement Mathématique, Université de Genève, 1972-1973.

[10] Urs Stammbach, Ein Zwischenfall dem Heinz Hopf 1939 in Karlsruhe ausgesetzt war, Mathematische Semesterberichte 56 (2009), 233-250. 


\section{Document 1}

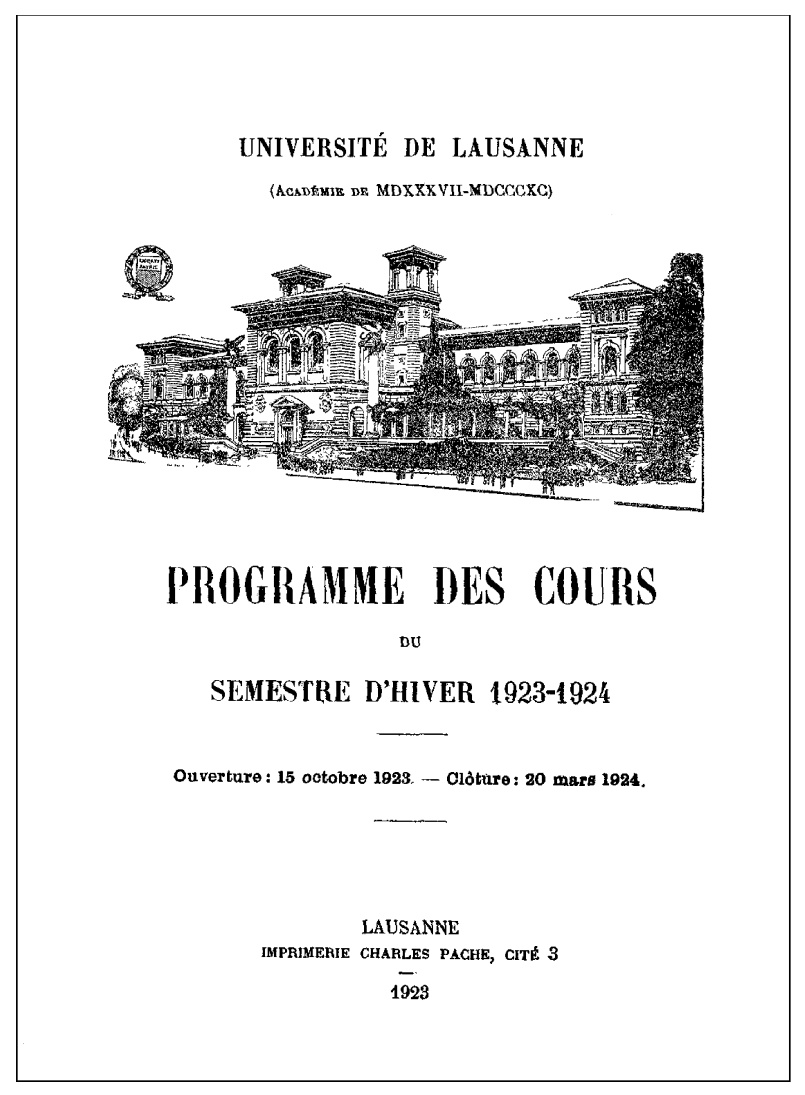

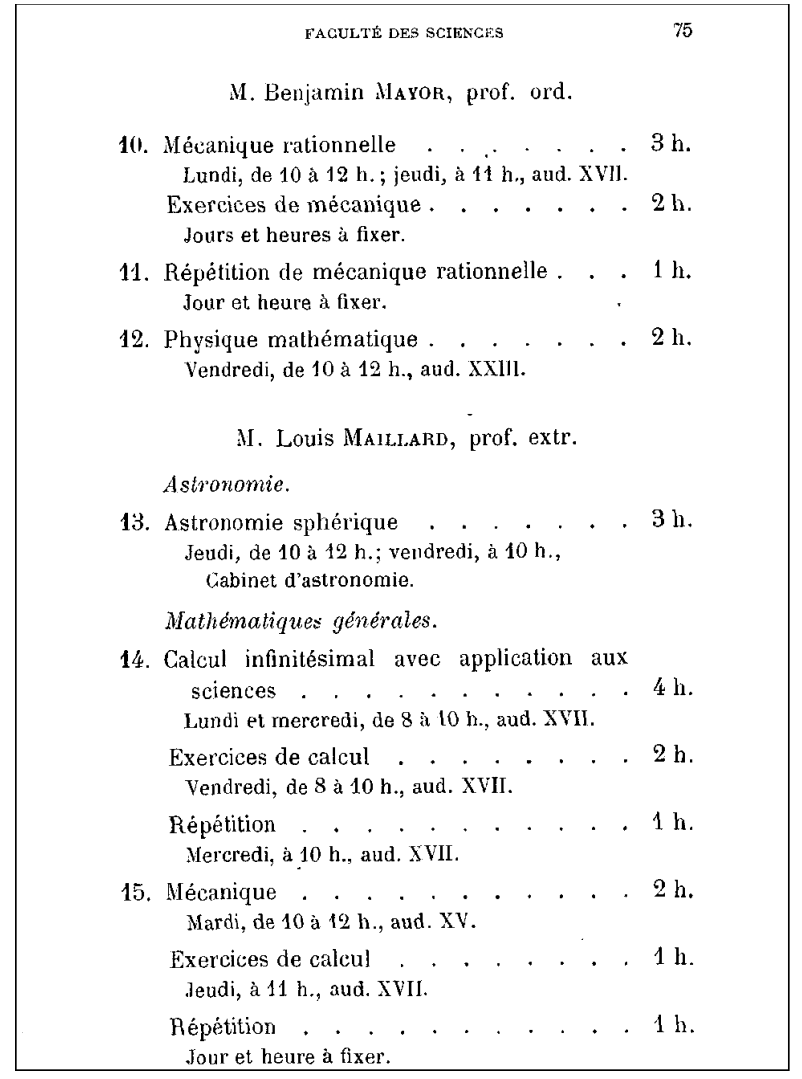

74 FACULTÉ DES SCIENCES

SECTION DES SCIENCES MATHÉMATIQUES, PHYSIQUES ET NATURELIES

a) Sciences mathématiques.

M. Gustave Dumas, prof. ord.

?. Calcul différentiel et intégral . . . . $6 \mathrm{~h}$. Lundi, jeudi et samedi, de 10 à 12 his, aud. XV. Exercices de calcul . . . . . . 2 h. Répétition . . . . . . . . 1 h.

2. Géométrie infinitésimale. . . . . $3 \mathrm{~h}$. Mardi, à $18 \mathrm{~h}$, ; vendredi, de 17 à 19 h., aud. XXII.

$$
\text { M. (vacat.) }
$$

3. Théorie des fonctions . . . . . . $3 \mathrm{~h}$.

4. Questions diverses d'analyse . . . . . $2 \mathrm{~h}$.

5. Séminaire mathématique. . $2 \mathrm{~h}$. par quinzaine. Jours et heures à fixer.

\section{Marius LACOMBE, prof. ord.}

6. Géométrie descriptive . . . . . $4 \mathrm{~h}$. Mardi et jeudi, de 8 à $10 \mathrm{~h}$., aud. XV.

7. Epures. . . . . . . . . . . $4 \mathrm{~h}$. Jeudi, de 14 à 18 h., aud. XXXI.

Répétition . . . . . . . 1 h. Jour et heure à fixer.

8. Géométrie analytique. . . . . . . $3 \mathrm{~h}$. Mercredi, de 10 a $12 \mathrm{~h}$; ; vendredi, à $11 \mathrm{~h}$., aud. XV.

Répétition de géométrie analytique . . . $1 \mathrm{~h}$. Jour et heure à fixer.

9. Géométrie de position avec exercices. . . $3 \mathrm{~h}$. Mardi, de 15 à 18 h., aud. XXXI.

\section{6}

faculté des scaences

II. Samuel Dumas, prof, extr.

16. Cálcul des probabilités, $\mathrm{l}^{\mathrm{re}}$ partie . . . . $3 \mathrm{~h}$. Mardi, de 16 à 18 h.; jeudi, à 9 h., aud. IX.

b) Seiences physiques et nalurelles.

II. Albert Pekrier, prof. ord.

17. Physiquue expérimentale, $\mathrm{I}$. . . . . $5 \mathrm{~h}$. Lundi et mardi, de 10 a 12 h.; mercedi, à $10 \mathrm{~h}$, aud. Xiv.

18. Manipulations pour débutants. I après-midi. Jeudi ou vendredi, dle 14 à $18 \mathrm{~h}$.

19. Travaux pour étudiants avancés et travaux de recherches. Tous les jours.

$$
\text { M....(vacat) }
$$

20. Physique générale, 11 . . . . . . . $5 \mathrm{~h}$. Jeudi, de 9 a 11 h. ; vendredi, de 10 à 12 h.; samedi, à 9 h., aud. XIV.

Répétitions . . . . . . . . . $1 \mathrm{~h}$. Jour et heure a fixer.

M. Constant Durolr, prof. extr.

21. Spectroscopie . . . . . . . $1 \mathrm{~h}$. Jour et heure à fixer, aud. $\mathrm{X}$.

\section{Paul Durort, prof. ord.}

22. Electrochimie appliquée (chapitres choisis). $2 \mathrm{~h}$ Jours et heures à fixer.

23. Laboratoire pour étudiants avancés; travaux de recherches. Tous les jours. 


\section{Document 2}

Châteauroux 21 novembre 1940

\section{Cher Monsieur}

J'ai bien reçu les tirages à part de vos travaux que vous avez eu l'amabilité de m'envoyer, et je vous en suis infiniment reconnaissant.

Cela m'est d'autant plus utile que presque tous mes livres sont restés à Strasbourg et doivent être considérés comme perdus.

MM. Ehresmann et A. Weil sont actuellement à Clermont Ferrand (puy de Dôme). M. Ehresmann est professeur à la Faculté des Sciences, 34 avenue Carnot. M. Weil attend son départ pour l'Amérique.

Je m'intéresse surtout à des questions de topologie (espaces fibrés, parallélisme absolu dans les sphères, propriétés d'homotopie du groupe orthogonal etc.), et serais heureux de rester en rapport avec l'École Suisse qui s'intéresse à ces mêmes questions.

Veuillez agréer, cher Monsieur, l'assurance de ma considération respectueuse.

J. Feldbau

\section{Document 3}

Mon cher ami,

Me voici soldat depuis quelques semaines, après des péripéties compliquées dont je vous ferai le récit un jour et dont votre cousin (de la Légation Suisse à Londres) vous a peut-être dit quelque chose. Ma situation actuelle est enviable à bien des points de vue: à la campagne, quelque part dans le Cotentin, non loin de la mer; le seul risque que je cours est d'engraisser.

Je serais heureux d'avoir de vos nouvelles, de vous et de vos travaux. Pour moi, j'ai bien travaillé pendant quelques mois que j'ai récemment passés en prison, de février au début de mai. Vous avez dû recevoir ou vous allez recevoir incessamment une quinzaine de tirages à part d'une note aux Comptes-Rendus sur les corps de fonctions algébriques à corps des constantes finis. Je vous serais très obligé de bien vouloir en transmettre quelques-uns à tous ceux que le sujet peut intéresser, et à qui il me serait difficile de l'expédier moi-même actuellement. Je dois dire que je n'ai pas eu le temps de combler toutes les lacunes dans mes démonstrations; le lemme essentiel (qui exprime le degré d'une correspondance par une trace) se démontre facilement, en théorie classique, par les fonctions thêta; j'ai transposé une partie de la théorie de ces fonctions au cas abstrait, mais pas assez pour démontrer le lemme en question. Je ne crois pas cependant y trouver de grande difficulté quand je reprendrai la question.

Bourbaki, jusqu'à ces tout derniers temps, a continué son activité. Vous avez dû recevoir le fascicule 1, paru en février; les suivants (Topologie Générale) sont sous presse ou bien sur le point d'être envoyés à l'impression. L'intégration, qui nous avait longtemps arrêtés, est bien en route. Bien entendu, tout cela a dû être momentanément interrompu. Je commence aussi à y voir clair dans les intégrales de formes différentielles, l'idée étant en gros la suivante: par une forme de degré $p$ dans une multiplicité $M^{n}$, j'entends une distribution de masse sur une partie compacte de l'espace des simplexes $S^{n-p}$ dans $M^{n}$; cela comprend comme cas particuliers, d'une part le variétés $V^{n-p}$, de l'autre les formes «classiques» de degré $p$, et même tous vos «courants». Ecrivez-moi ce que vous en pensez (très probablement vous avez dû y penser de votre côté). Par une distribution de masse sur un espace compact j'entends naturellement une mesure de Radon, ou ce qui revient au même une fonctionnelle linéaire continue des fonctions continues, $\int f(x) d \mu(x)$.

Pour l'instant, mon adresse est: Soldat Weil André, $3^{\underline{e}}$ Section de la 205르 C.M.P., Saint-Vaast-La Hougue, Manche. Mais le plus commode sera encore que vous m'écriviez à mon adresse de Paris, d'où mon courrier me suit.

Meilleures amitiés

A. Weil 


\section{Document 4}

UNIVERSITÉ DE LAUSANNE FACULTÉ DES SCIENCES

\section{Les formes différentielles harmoniques}

THÈ SE

PRésentég a LA Faculté des sciences de L'UNiverstté DE LAUSANNE OUR L'OBTENTION DU GRADE DE DOCTEUR ESS SCIENCES

PAR

PIERRE BIDAL

(Soutenue le 20 décembre I945)

(Extrait des Commentarii Mathematici Helvetici)

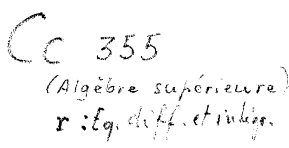

$\mathrm{ZURICH}$

ORELL YUSSLI ARTS GRAPHIQUES S.A.

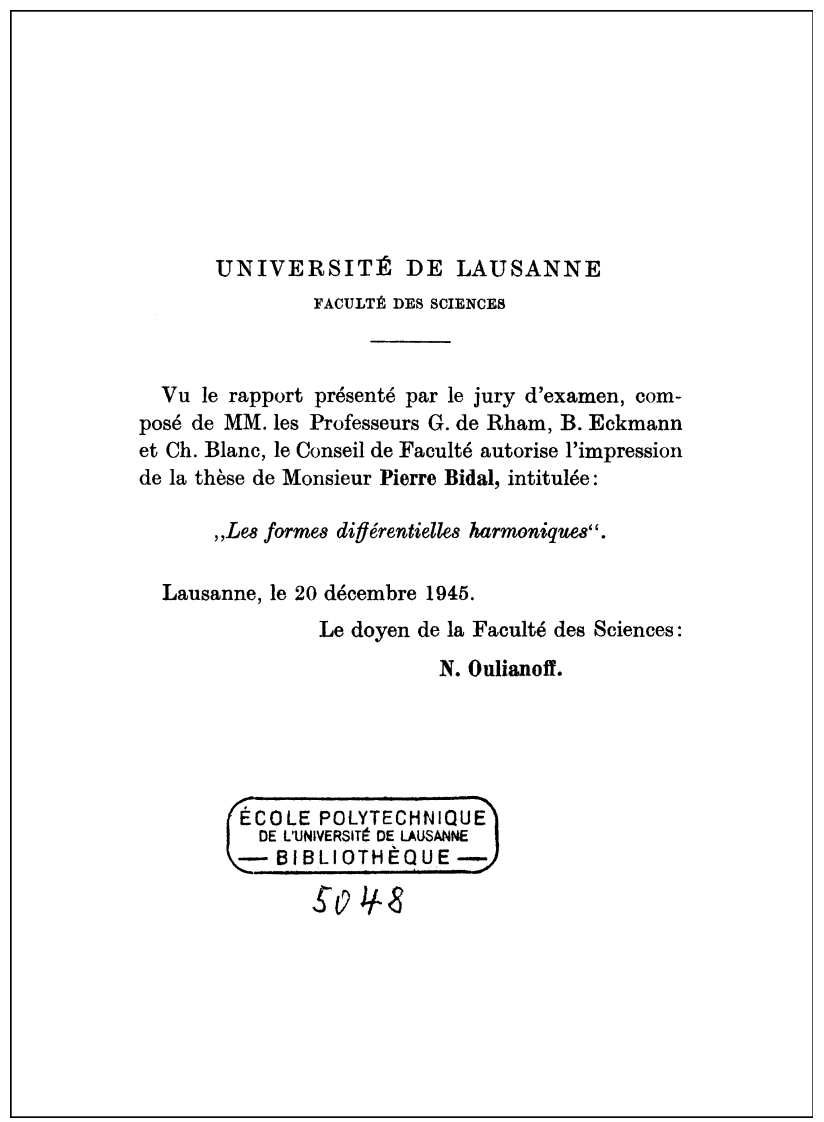

\section{AVANT-PROPOS}

C'est en 1940 que j'ai abordé, sous la direction de M. le professeur de Rham, l'étude des formes différentielles harmoniques. Les résultats que j'ai obtenus ont été simplifiés sur certains points et complétés sur d'autres par M. de Rham et c'est à lui qu'est due la rédaction définitive du présent travail. Je tiens à lui exprimer ici toute ma gratitude pour les encouragements et l'aide qu'il m'a donnés.

Voici quelles sont les principales questions auxquelles j'ai apporté une contribution personnelle:

1) J'ai obtenu la définition de l'opérateur $\Delta$ (cf. Ch. I, § 3) avec l'aide de M. de Rham.

2) J'avais prévu que la forme $\Delta_{x} \omega_{p}(x, y)$ appartient à l'exposant $n-2$, mais les démonstrations quel'on trouvera au chapitre II sontde M.de Rham.

3) J'avais obtenu l'expression même des équations (I) et (II) (Ch. II, $\S 6$ ) et les calculs du $\S 11$ (Ch. II) sont à quelques détails près ceux que j'ai établis moi-même.

4) En faisant appel aux formules d'orthogonalité que m'avait communiquées M. de Rham, j'ai vu que l'équation $\Delta \mu=0$ est équivalente, globalement, au système $\left\{\begin{array}{l}d \mu=0 \\ \delta \mu=0\end{array}\right.$ (cf. Ch.I, § 4).

5) J'ai reconnu que la méthode de la paramétrix de Hilbert est applicable à l'équation $\Delta \mu=\beta$ (cf. démonstration du th. H. Ch. III, § 14).

6) Je signalerai encore que j'avais établi une théorie correcte des équations intégrales portant sur des formes différentielles. Cette théorie, selon une idée de $M$. Hodge lui-même [7] $]^{1}$ ) mais non développée par lui, se fondait sur la définition de déterminants dont les éléments sont des formes différentielles. Ces calculs m'avaient permis de m'assurer de la validité des théorèmes de Fredholm dans le cas des équations intégrales envisagées ici.

7) Je crois avoir apporté une contribution modeste, mais utile, à l'étude des équations intégrales de Fredholm en établissant la validité sans restriction des second et troisième théorèmes de Fredholm dans le cas de noyaux non bornés dont un itéré est borné (Appendice: lemme 2).

P. B.

1) Les numéros entre crochets renvoient à l'index bibliographique placé après l'introduction. 


\section{Document 5}

Charles Ehresmann

11 , rue de l'Observatoire

Strasbourg

Strasbourg, le 3 janvier 1946

Mon cher ami,

Comment pourrais-je vous expliquer mon silence depuis la libération de notre pays? Je suis inexcusable de ne pas vous avoir donné de signe de vie autrement que par l'envoi de deux petits tirages à part. C'est une suite de soucis mesquins qui est cause de ma négligence; depuis plus de six mois je n'ai même plus répondu aux lettres de mes amis. J'espère que je pourrai enfin retrouver ma vie normale et penser sérieusement aux mathématiques.

Ce n'est plus guère le moment de vous parler de ce qui s'est passé autour de moi dans la dernière phase de la guerre et après le libération. Vous savez qu'à Clermont nous avons eu quelques alertes sérieuses: des rafles par la Gestapo et des arrestations en grand nombre. Plusieurs fois je me suis senti menacé directement, principalement au moment de l'arrestation de mon beau-frère qui a été très actif dans la lutte clandestine contre les Allemands (Il a été déporté en Allemagne et comme il n'a plus donné aucun signe de vie nous avons abandonné tout espoir de le revoir). Personnellement je n'ai jamais été inquiété, peut-être parce qu'à plusieurs reprises j'ai vécu retiré à la campagne. Mes collègues mathématiciens et particulièrement les membres du groupe Bourbaki sont tous sortis indemnes de cette guerre, à l'exception de ce pauvre Jacques Feldbau qui a été déporté en Allemagne et y est mort d'épuisement quelques jours à peine avant la libération de son groupe de déportés par les Américains. Vous avez sans doute appris aussi la mort de nos deux philosophes mathématiciens: Jean Cavaillès fusillé par les Allemands au début de 1944 et Albert Lautman fusillé à Bordeaux comme otage la veille de la libération de Bordeaux. La liste des victimes de la guerre et de la Gestapo parmi mes amis et dans mon entourage est terriblement longue. Depuis avril 1945 j'ai fait plusieurs voyages à Strasbourg et je suis définitivement ici depuis le premier septembre dernier. Je ne vous décris pas la joie que j'ai éprouvée à retrouver cette ville passablement mutilée par les bombardements mais toujours belle. Seulement la réinstallation à Strasbourg a posé un tas de petits problèmes dont le plus embêtant a été celui du logement. Il m’a déjà fait perdre tellement de temps que je n'ai aucune envie d'en parler aussi dans cette lettre. En fait, nous sommes installés dans un appartement que nous cherchons à quitter à la première occasion parce qu'il est trop vaste et sans confort. Mais vu la crise du logement, nous risquons d'y être encore quand vous viendrez nous faire une visite à Strasbourg.

Je vous rappelle en effet votre promesse de faire une nouvelle visite à notre Université après son retour à Strasbourg. Je serais très heureux si vous pouviez tenir cette promesse au cours de cette année scolaire. Les circonstances ne permettrons sans doute pas encore l'organisation d'une brillante réunion de mathématiciens, comme je l'aurais souhaité pour marquer la reprise de notre activité à Strasbourg. Mais si vous vouliez bien accepter de faire ici une ou plusieurs conférences, vous seriez assuré de trouver un petit cercle d'auditeurs auxquels vous feriez un très grand plaisir. Parmi eux il y aurait mes collègues mathématiciens et une dizaine de mes élèves qui s'intéressent à la Topologie. J'ai en effet commencé un cours de Topologie où, après une introduction à la Topologie générale (comprenant essentiellement le chapitre I de la Topologie de Bourbaki), je compte développer la théorie des espaces fibrés et ses applications aux variétés différentiables et aux groupes de Lie. Au deuxième semestre il y aura de même un cours de Topologie algébrique (Homologie) par Henri Cartan. Vous savez peut-être déjà que Henri Cartan s'est fait détacher de la Sorbonne pour revenir à Strasbourg. Je pense donc qu'il ne vous serait pas difficile de trouver un sujet qui intéresserait beaucoup de gens ici. Pour que les étudiants soient un peu mieux préparés à comprendre des exposés de Topologie (ou sur des sujets voisins), il conviendrait seulement de choisir une date du $2^{e}$ semestre, de préférence dans la première quinzaine d'avril ou dans la quinzaine après les vacances de Pâques. Avant la fin de l'hiver votre séjour à Strasbourg risquerait d'être peu agréable. Après le 15 mai il est fort possible que je sois moi-même absent de Strasbourg, car j'envisage d'aller passer l'été prochain à Rio de Janeiro. J'ai adressé une invitation analogue à Hopf et je voudrais inviter également Eckmann. Si possible, il serait peut-être intéressant de faire coïncider les dates de vos visites; cela formerait un petit meeting mathématique francosuisse. Le Centre National de la Recherche Scientifique a mis à ma disposition un petit crédit qui me permettrait de rembourser vos frais de séjour en France par une somme de 5000 francs.

Dans l'espoir d'une rencontre prochaine, nous vous adressons, ma femme et moi, nos meilleurs vœux pour l'année 1946.

Ch. Ehresmann 


\section{Document 6}

G. de Rham

Le 7 janvier 1947

7 , av. Bergières

Lausanne

Monsieur Laurent Schwartz

26, rue Saint-Michel

Nancy

Cher Monsieur,

Je vous remercie très sincèrement de vos tirés à part. Votre article des Annales de Grenoble m'a très directement intéressé, parce que vos idées permettent de donner une forme précise et générale à des notions un peu vagues que j’ai depuis l'époque où j'ai fait ma thèse, et que j'ai esquissées dans des conférences à Genève et à Hambourg (dont je vous envoie des tirés à part, avec quelques autres).

Comme vous pensez aussi à l'application de vos idées à l'étude théorique des variétés et des formes différentielles, ainsi que vous le dites dans l'Introduction, je me permets de vous communiquer quelques réflexions sur ce sujet, suggérées par votre article.

Dans l'espace à $n$ dimensions $E^{n}$, je considère les formes différentielles extérieures de degré $p$, à coefficients infiniment dérivables nuls hors d'un ensemble compact, et j'appelle distribution à $p$ dimensions dans $E^{n}$ toute fonctionnelle linéaire $T[\varphi]$ d'une telle forme $\varphi$, continue dans un sens facile à préciser comme dans votre définition. Le nombre $g=n-p$ sera dit le degré de la distribution $T$.

Une forme différentielle $f$ de degré $g$ définit une telle distribution, en posant

$$
f[\varphi]=\int_{E^{n}} f \varphi .
$$

Un champ d'intégration à $p$ dimensions $c$ aussi, en posant

$$
c[\varphi]=\int_{c} \varphi .
$$

Le couple $(c, f)$ d'un champ $c$ à $p+k$ dimensions et d'une forme $f$ de degré $k$ aussi, en posant

$$
(c, f)[\varphi]=\int_{c} f \varphi .
$$

Ainsi les distributions contiennent comme cas particulier ce que j'appelais courant à $p$ dimensions.

Le produit extérieur d'une distribution $T$ de degré $g$, par une distribution $f$ de degré $g^{\prime}$ qui est égale à une forme différentielle à coefficients infiniment dérivables, se définit naturellement en posant $T f[\varphi]=T[f \varphi]$. C'est une distribution de degré $g+g^{\prime}$. Cela étant, on reconnaît que toute distribution $T$ de degré $g$ peut se mettre d'une manière unique sous la forme

$$
T=\sum T_{i_{1} \ldots i_{g}} d x^{i_{1}} \cdots d x^{i_{g}}
$$

d'une somme de produits où $T_{i_{1} \ldots i_{g}}$ sont des distributions de degré 0 .

La différentielle $d T=\sum d T_{i_{1} \ldots i_{g}} d x^{i_{1}} \cdots d x^{i_{g}}$ se définit directement en posant $d T[\varphi]=(-1)^{g+1} T[d \varphi]$. Si $g=0$, on définit $\frac{\partial T}{\partial x_{i}}$ en posant $d T=\sum \frac{\partial T}{\partial x_{i}} d x_{i}$ : c'est bien votre définition.

Si $T$ est un champ $c, d T$ est (au signe près) le champ égal au bord de $c$.

Avec ces définitions, les théorèmes que j'ai établis au chap. 3 de ma thèse s'étendent aux distributions, et les mêmes méthodes de démonstration s'appliquent presque sans changements.

Ainsi, dans $E^{n}$, toute distribution $T$ fermée (c'est à dire telle que $d T=0$ ) de degré $g$ est égale à la différentielle $d S$ d'une distribution $S$ de degré $g-1$ (si $g>0$ ); se réduit à une constante si $g=0$. Ce dernier point, qui n'est autre que votre théorème „Une distribution dont toutes les dérivées sont nulles est égale à une constante“, découle ainsi du lemme II, chap. 3 de ma thèse: soit $\varphi_{0}$ une forme particulière de degré $n$ telle que $\int_{E^{n}} \varphi_{0}=1$, soit $\varphi$ une forme quelconque de degré $n$ ( $\varphi$ et $\varphi_{0}$ sont nulles en dehors d'un certain cube à $n$ dimensions $C$ ) et soit $k=1[\varphi]=\int_{E^{n}} \varphi$; d'après le lemme 2 il existe une forme $\bar{\varphi}$ nulle hors de $C$ telle que $d \bar{\varphi}=\varphi-k \varphi_{0}$ d'où $T[\varphi]=k T\left[\varphi_{0}\right]: T$ se réduit à la constante $T\left[\varphi_{0}\right]$. 
Sur une variété close, au lieu de $E^{n}$, une distribution fermée dont toutes les périodes sont nulles est homologue à zéro. Il faut définir les périodes d'une distribution fermée $T$ comme étant les valeurs de $T[\varphi]$ pour une forme $\varphi$ fermée.

Tout cela est si simple et facile après la lecture de votre article, que je ne doute pas que vous n'ayez déjà pensé à tout cela.

Sur un espace de Riemann, la distribution adjointe $T^{*}$ à une distribution $T$ se définit en posant $T^{*}[\varphi]=(-1)^{p g} T\left[\varphi^{*}\right]$, $p$ étant la dimension de $T$ et le degré de $\varphi^{*}, g=n-p$ la dimension de $T^{*}$ et le degré de $\varphi$. Les opérateurs que j'ai appelés $\delta$ et $\Delta$ s'appliquent alors aux distributions. Je crois avoir reconnu qu'avec l'aide de la méthode que j'ai exposée à Strasbourg pour les formes différentielles harmoniques (et qui va paraître aux Annales de Grenoble) on peut prouver que toute distribution harmonique est égale à une forme différentielle harmonique (ce qui fait prévoir le caractère totalement elliptique de l'opérateur $\Delta$ ). On peut montrer aussi que l'équation $\Delta T=S$, où $S$ est donnée, a une solution $T$ si $S$ est orthogonale aux formes harmoniques, c'est-à-dire si $S\left[\varphi^{*}\right]=0$ pour toute forme harmonique $\varphi$ de même degré que $S$, et ce que j'ai appelé le théorème de décomposition s'étend alors aux distributions.

Mais cela appelle encore des recherches, il y a encore bien des problèmes qui méritent d'être étudiés dans cette théorie des formes différentielles harmoniques. Je crois qu'on ne pourra plus le faire sans utiliser vos idées.

C'est vous dire tout l'intérêt que j'y porte et avec quelle impatience j'attends la monographie que vous nous annoncez.

En vous félicitant très vivement et sincèrement, et en vous remerciant encore de votre envoi, je vous prie de croire, cher Monsieur, à mes sentiments les meilleurs.

G. de Rham

\section{Document 7}

FACULTÉ

DES SCIENCES

\section{MATHÉMATIQUES}

Nancy, le 3 février 1947

\section{Cher Monsieur,}

je ne suis rentré que récemment d'un séjour à Paris, et j'ai été très heureux de trouver ici vos tirages à part et votre lettre. Naturellement la topologie n'a pas été étrangère à mes recherches. Je me souviens avec intérêt d'une conversation que nous avons eue à Clermont-Ferrand (à la Marquise de Sévigné, si je ne me trompe!) en 1942, à la suite d'une conférence que vous aviez faite pour la faculté de Strasbourg. Je connaissais vos travaux sur les „courants“ et vous m'avez indiqué qu'il y aurait intérêt à unifier d'une façon simple la théorie des champs et celle des formes (unification réalisée pour les dimensions 0 et $n$ sur une variété à $n$ dimensions par l'intégrale de Stieltjes).

Les idées que vous développez dans votre lettre sont bien celles que j'avais, et les démonstrations à peu près identiques. J'en ai parlé à «Bourbaki» l'année dernière lors de la présence de Chevalley à Paris. J'ai en vue encore d'autres applications (notamment aux groupes de Lie). Je suis malheureusement très surchargé de travail et je manque de temps pour mettre tout cela au point. En ce qui concerne les formes harmoniques, je pense aussi qu'on peut leur appliquer avec fruit la théorie des distributions, mais je n’y ai jamais réfléchi: je serais très heureux que vous fassiez progresser la question!

J'ai commencé la rédaction de la monographie. Je ne sais pas bien encore ce que je mettrai dedans. Les développements relatifs aux transformations de Fourier et Laplace (calcul symbolique) sont assez longs. Il est possible, pour ne pas trop allonger, que je réunisse les résultats topologiques dans un mémoire séparé. De toute façon je vous enverrai dès que possible une copie dactylographiée du manuscrit, quand je l'aurai terminé!

Je vous remercie encore. J'ai été particulièrement content de voir que mes idées trouvaient chez vous un écho aussi favorable.

Croyez à mes sentiments dévoués

L. Schwartz 


\title{
Document 8
}

Kähler

Leipzig W33 Markt 2 II $r$

Deutschland

Leipzig, den 20.4.47

Sehr geehrter Herr Professor!

Mein Sohn Erich Kähler bittet mich aus seinem Gefangenlager doch einmal an Sie zu schreiben und Sie zu bitten, ihm wieder einige Sonderabdrücke über Ihre Arbeiten, insbesondere über die Theorie von Hodge (Comm. Helv. 19 u. Ann. Grenoble) zu schicken. Er habe alle die wertvollen Sonderabdrücke verloren, auch alle seine Bücher und wäre Ihnen sehr dankbar dafür.

Es ist ihm nicht gestattet viel Briefe zu schreiben, so bittet er mich darum, mich an Sie zu wenden. Seine Adresse ist: Oberleutnant Erich Kähler - Gefangennummer 831623, Depôt n 401/II/13 Komp. Le Mans (Sarthe), Frankreich.

Für Ihre Bemühungen herzlichsten Dank.

Hochachtungsvoll Frau Elsa Kähler

\section{Document 9}

\section{DISCOURS SUR L'GEVRE DE M. HEINZ HOPF, 16.12.1965}

\author{
Georges de Rham
}

C'est avec plaisir que j'accepte, à la demande de Monsieur le Doyen de la Faculté des Sciences, de parler ici de l'œuvre mathématique du Professeur Heinz Hopf. Avec plaisir, mais aussi avec appréhension car il m'est vite apparu impossible de faire en quelques minutes une revue même extrêmement sommaire d'une œuvre aussi considérable. Aussi je me bornerai à en relever quelques aspects, en essayant de faire pressentir le rôle qu'elle a joué dans l'évolution des Mathématiques depuis quarante ans.

En tête de l'imposante liste des publications du professeur Hopf, nous trouvons un mémoire intitulé "Zum CliffordKleinschen Raumproblem". C'est la première partie d'une thèse de doctorat, présentée à l'Université de Berlin en 1925 et parue dans les Mathematische Annalen. Le problème qui en fait l'objet consiste à déterminer les espaces doté d'une métrique à courbure constante positive. La donnée est donc une propriété géométrique locale de l'espace: courbure constante positive. Il s'agit d'en tirer les conséquences pour sa structure globale. Et la méthode de résolution fait intervenir la théorie des groupes, c'est-à-dire des notions d'Algèbre abstraite.

Dans le beau volume publié récemment par l'École polytechnique fédérale sous le titre Selecta Heinz Hopf, ce premier travail ne figure pas. Faisant un choix, on a retenu d'autres travaux certes beaucoup plus importants, et tout choix implique des sacrifices. Cependant, il est intéressant de voir dans cette thèse de doctorat quelques caractères qui distinguent toute l'œuvre ultérieure de son auteur. D'abord, le choix d'un problème géométrique précis, qui excite l'imagination, et qui comporte ce passage du local au global qui conduit inéluctablement à la Topologie, dont il va être question dans un instant. Ensuite, une méthode d'attaque faisant appel à l'Algèbre abstraite. Enfin et surtout, un problème riche en substance, contenant en puissance des prolongements féconds, comme l'ont montré par exemple la thèse de notre collègue Georges Vincent, faite sous la direction même du professeur Hopf, et les récents et importants travaux du jeune mathématicien américain Joseph Wolf.

En 1925, la Topologie était encore dans l'enfance. Les fameux mémoires du grand Henri Poincaré sur l'Analysis Situs, comme on appelait alors cette discipline, en avaient donné les bases au début de ce siècle. Mais ces mémoires pleins d'idées géniales contenaient aussi des obscurités et manquaient souvent de rigueur. Une seconde étape importante est marquée par le profond mathématiciens hollandais Léonard Brouwer dans ses travaux d'une rigueur inattaquable, mais trop difficiles pour l'immense majorité des mathématiciens de l'époque. Aussi la Topologie était-elle considérée en général comme un champ un peu en marge des mathématiques et on la cultivait peu. Pourtant, en un sens, c'était l'âge d'or de cette discipline. Elle offrait au jeune chercheur un immense terrain vierge.

Aujourd'hui, cette Topologie occupe une place centrale dans les mathématiques, comme l'Algèbre. Elle fait l'objet de cours et d'examens dans les Universités, les publications qui s'y rapportent ne se compte plus. Mais que les jeunes se rassurent, il y a encore beaucoup à moissonner et les problèmes sont encore nombreux qui attendent leur solution. 
Ce prodigieux développement est dû dans une très large mesure à l'œuvre de Heinz Hopf. Voici quelques unes des directions où il a donné une impulsion décisive.

Poincaré et Brouwer avaient montré que, sur les sphères de dimension paire, tout champ de vecteurs a au moins un point singulier. Dans un travail fondamental, Hopf montre qu'il en est de même sur toutes les variétés dont la caractéristique de Euler-Poincaré n'est pas nulle, et sur celles-là seulement. Il pose le problème analogue pour les système de champs de vecteurs et la thèse de $\mathrm{M}$. Stiefel, faite sous sa direction, est à l'origine d'un des chapitre importants de la Topologie, la théorie des classes caractéristiques. Hopf attire l'attention sur le difficile problème que présentent à cet égard les sphères. Un premier résultat important est obtenu, sous son impulsion, par M. Eckmann, puis une véritable compétition internationales s'engage et suscite les travaux de Henry Whitehead, Steenrod, Kervaire, et enfin Frank Adams.

Une autre direction, d'ailleurs connexe car tout se tient, c'est la théorie de l'homotopie, à laquelle de beaux théorèmes de Hopf et la découverte de ce qu'on appelle aujourd'hui l'invariant de Hopf ont donné aussi une impulsion extraordinaire. Il faut mentionner la topologie des espaces de groupes et de leur généralisations, qu'on appelle aujourd'hui les espaces de Hopf (ou $H$-espaces). Et, dans une direction très différente, les deux mémoires intitulés "Le groupe fondamental et le deuxième groupe de Betti" et "Sur les groupes de Betti d'un groupe quelconque" sont véritablement la source d'une immense série de travaux qui ont constitué un nouveau chapitre important de l'Algèbre, l'Algèbre homologique.

J'arrêterai ici cette énumération très incomplète, et je parlerai pas des travaux pourtant aussi très importants de pure Géométrie. Toutes les publications de Heinz Hopf se distinguent par leur présentation d'une clarté et d'une élégance parfaites. Ce souci de la forme et de la présentation, malheureusement trop rare aujourd'hui, est sans doute l'une des causes du succès de l'enseignement du professeur Hopf, à côté du charme de sa personnalité, empreinte de modestie et d'humour, et de son hospitalité si cordiale. Qu'il me soit permis, à ce propos, de rendre un très respectueux hommage à Madame Heinz Hopf, que la maladie empêche aujourd'hui d'être autrement qu'en pensée avec nous.

Une trentaine de jeunes mathématiciens ont fait leur thèse de doctorat sous la direction du professeur Hopf. La plupart occupent maintenant des chaires universitaires, en Suisse et à Lausanne en particulier, dans plusieurs pays d'Europe et d'Amérique.

Dans le Colloques et les grands congrès internationaux, la participation du professeur Hopf a toujours été essentielle. En Suisse, nous sommes fiers de le compter parmi les nôtres et nous lui sommes reconnaissant de sa fidélité que les appels flatteurs de grandes universités étrangères n'ont pas réussi à ébranler.

Nombreuses sont les distinctions dont il a été honoré. Citons en particulier:

Dr. Phil. Universität Berlin, 1925

Membre de la Société mathématique de Moscou, 1930

Dr. Sc. h.c. Princeton University, 1947

Korrespondierendes Mitglied der Heidelberger Akademie der Wissenschaften, 1949

Gauss-Weber Medaille, Göttingen, 1955

Honorary Member London Mathematical Society, 1956

Foreign Associate National Academy of Sciences of the USA, Washington, 1957

Membre honoraire de la Société Mathématique Suisse, 1957

Dr. der Naturwissenschaften h.c., Universität Freiburg /Br., 1957

Dr. sc. h.c. University of Manchester, 1958

Mitglied der Deutschen Akademie der Naturforscher Leopoldina, Halle, 1958

Foreign Honorary Member American Academy of Arts and Sciences, Boston, 1961

Member American Philosophical Society held at Philadelphia for promoting useful knowledge, 1962

Socio straniero dell'Accademia nazionale dei Lincei, Roma, 1962

Dr. h.c. de l’Université de Paris, 1964

Dr. h.c. de la Faculté des sciences, Université libre de Bruxelles, 1965

Nous sommes heureux que l'Université de Lausanne puisse, à son tour, lui témoigner aujourd'hui notre admiration et notre reconnaissance 